Article

\title{
Ore Genesis of Shanmen Ag Deposit in Siping Area of Southern Jilin Province, NE China: Constraints from Fluid Inclusions and $\mathrm{H}-\mathrm{O}, \mathrm{S}, \mathrm{Pb}$ Isotopes
}

\author{
Xinhao Sun ${ }^{1} \mathbb{D}$, Yunsheng Ren ${ }^{1,2, *}$, Peng Cao ${ }^{1}$, Yujie Hao ${ }^{1,3}$ and Yu Gao ${ }^{1}$ \\ 1 College of Earth Sciences, Jilin University, Changchun 130061, China; sxh610062132@126.com (X.S.); \\ caopengnb@163.com (P.C.); rouyangyang@163.com (Y.H.); 15764327656@163.com (Y.G.) \\ 2 Institute of Disaster Prevention, Beijing 101601, China \\ 3 Key Laboratory of Mineral Resources Evaluation in Northeast Asia, Ministry of Natural Resources of China, \\ Changchun 130026, China \\ * Correspondence: renys@jlu.edu.cn; Tel.: +86-13154370506
}

Received: 25 August 2019; Accepted: 27 September 2019; Published: 27 September 2019

\begin{abstract}
The Shanmen Ag deposit, located in the southeastern part of the Siping area, Jilin Province, is one of the large-scale Ag deposits in Northeastern (NE) China. Almost all Ag orebodies, Ag-bearing quartz-sulfide veins are strictly controlled by NE-trending faults or brittle fractures and are hosted in the Yanshanian monzonite and quartz diorite. In terms of deposit geology, three mineralization stages are recognized: the pyrite-quartz stage (I), the quartz-Ag-polymetallic sulfide stage (II), and the carbonate-quartz stage (III). The research results of the fluid inclusions in the different stages indicate that the early stage (Stage I) mainly contains three types of fluid inclusions: liquid-rich two-phase (L-type), vapor-rich two-phase (V-type), and $\mathrm{CO}_{2}$ aqueous multi-phase (C-type). The fluid belongs to a medium-high temperature and medium-low salinity $\mathrm{H}_{2} \mathrm{O}-\mathrm{NaCl}-\mathrm{CO}_{2}$ system and has boiling characteristics. The middle stage (Stage II) is mainly characterized by liquid-rich two-phase (L-type) and vapor-rich two-phase (V-type) inclusions, in which the mixing of fluids of different nature leads to the escape of $\mathrm{CO}_{2}$. Only liquid-rich two-phase (L-type) inclusions are distinguished in the late stage (Stage III). The fluids of two later stages belong to the medium-low-temperature and low-salinity $\mathrm{H}_{2} \mathrm{O}-\mathrm{NaCl}$ system. Homogenization temperatures from the early to late stages range from 272.2 to $412.5^{\circ} \mathrm{C}, 124.1$ to $313.3{ }^{\circ} \mathrm{C}$, and 128.6 to $224^{\circ} \mathrm{C}$, respectively. Fluid salinities in the early to late stages range from 1.6 to $12.1,1.4$ to 8.9 , and 0.4 to $5.8 \mathrm{wt} . \% \mathrm{NaCl}$ equivalent, respectively. The gradually decreasing trends of homogenization temperatures and salinities and the reduction in the $\mathrm{CO}_{2}$ content indicate that the release of $\mathrm{CO}_{2}$ and the low-temperature environment are important causes of the precipitation of Ag-bearing minerals. The $\delta^{18} \mathrm{O}_{\mathrm{H} 2 \mathrm{O}}$ values of the ore-bearing quartz veins in the different stages range from -3.7 to $+8.1 \%$, and the $\delta \mathrm{D}$ values of fluid inclusions in the quartz range from -113 to $-103 \%$, indicating that the initial ore-forming fluid was mainly derived from magma and that the input of meteoric water gradually increased during the mineralization process. The $\delta^{34} \mathrm{~S}$ values (ranging from $-11.4 \%$ o to $+1.8 \%$ o) and $\mathrm{Pb}$ isotope compositions $\left({ }^{206} \mathrm{~Pb} /{ }^{204} \mathrm{~Pb}=18.143-18.189\right.$, $\left.{ }^{207} \mathrm{~Pb} /{ }^{204} \mathrm{~Pb}=15.543-15.599,{ }^{208} \mathrm{~Pb} /{ }^{204} \mathrm{~Pb}=38.062-38.251\right)$ of sulfides suggest that the ore-forming materials have mixed mantle and crustal sources. Therefore, we propose that the release of $\mathrm{CO}_{2}$ and the low-temperature environment are important conditions for silver minerals precipitation, and the mixing of fluids of different nature is the dominant mechanism causing precipitation. The Shanmen Ag deposit can be classified as an intrusion-related medium-low temperature hydrothermal vein-type deposit.
\end{abstract}

Keywords: ore genesis; fluid inclusions; isotope geochemistry; Shanmen Ag deposit; Siping area in Jilin Province 


\section{Introduction}

Northeastern China (NE China) is located in the eastern part of the Central Asian Orogenic Belt (CAOB) and the northern margin of the North China Plate (Figure 1a). It has belonged to the Paleo-Pacific Metallogenic Belt since the Jurassic period. This area is one of the most important metal belts in China, hosting a large number of gold, silver, copper, lead, zinc, molybdenum, and iron deposits. The silver deposits in NE China are mainly distributed in the Lesser Xing'an Range, Eastern Jiamusi and Khanka Massif, as well as the Manzhouli area of Inner Mongolia (Figure 1b). The most well-known large deposits are the Chaganbragen Ag-Pb-Zn deposit, Eren Tolgoi Ag deposit, Jiawula Ag-Pb-Zn deposit in Xin Barag Right Banne, and the Shanmen Ag deposit in the Siping area.

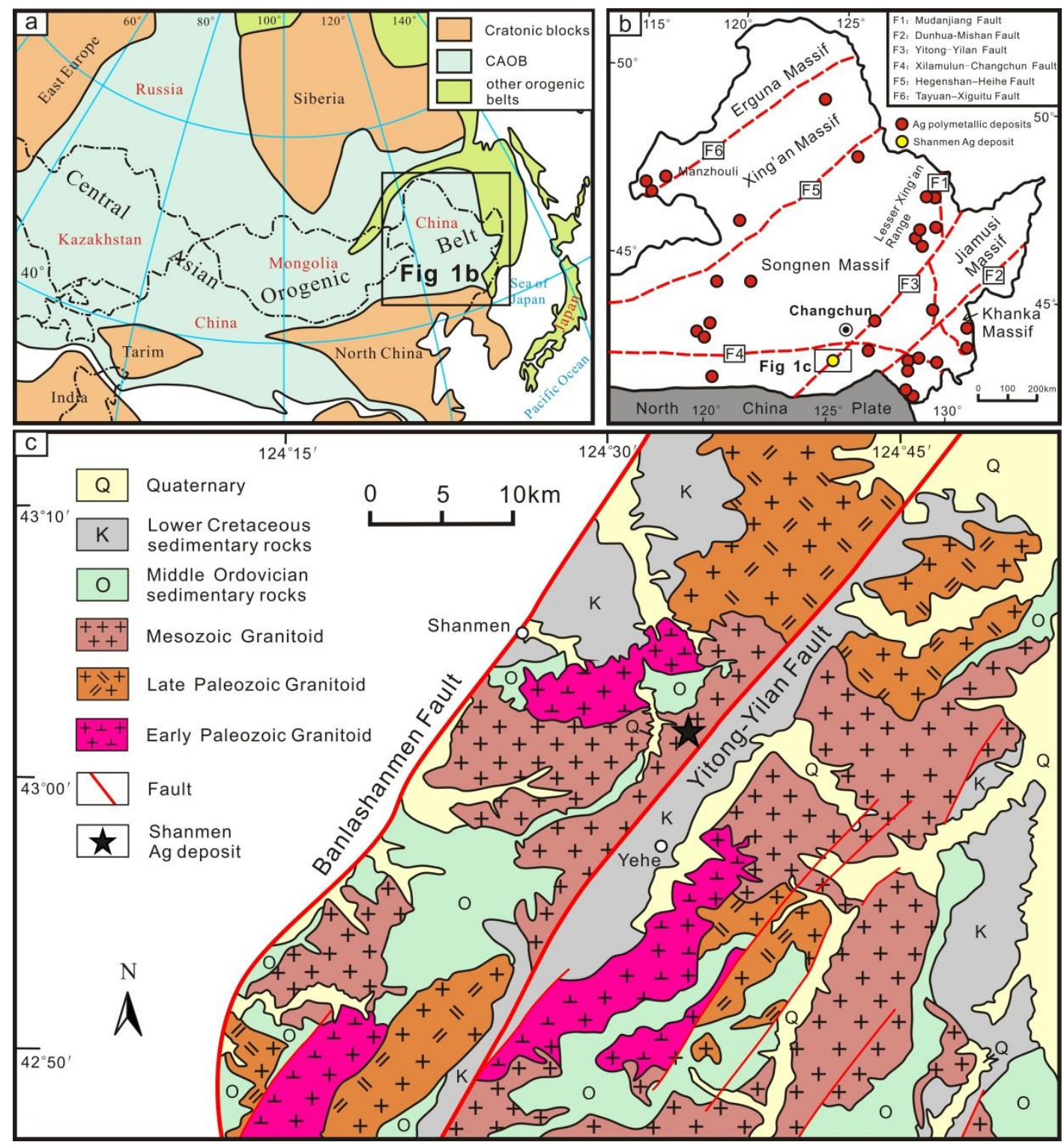

Figure 1. (a) General map of the Central Asian Orogenic Belt (after Safonova and Santosh [1]); (b) sketch map of the Northeastern (NE) China showing the distribution of Ag-polymetallic deposits (after Wu et al. [2]); (c) regional geological map of Shanmen-Yehe area in the central Jilin Province.

The Shanmen Ag deposit is located $11 \mathrm{~km}$ southeast of Shanmen County $\left(43^{\circ} 5^{\prime} 00^{\prime \prime} \mathrm{N}, 124^{\circ} 26^{\prime} 30^{\prime \prime} \mathrm{E}\right)$ (Figure 1c), and the tectonically accreted zone between the eastern section of the Xing'an Mongolian Orogenic Belt (eastern part of the CAOB) and the northern margin of the North China Plate. Its silver 
reserves exceed $1200 \mathrm{t}$ and have an average grade of $189.35 \mathrm{~g} / \mathrm{t}$, and the associated gold reserves are $7.8 \mathrm{t}$, with an average grade of $1.24 \mathrm{~g} / \mathrm{t}$. As one of the large-scale Ag deposits discovered in NE China, the Shanmen Ag deposit not only has important commercial value, but is significant for studying the metallogenesis of silver mineralization in NE China as well. Since the discovery of the deposit in the 1980s, studies of ore formation conditions, geological characteristics, and isotopic characteristics have been carried out, but a genetic classification of the type of mineralization remains controversial. Wang [3], Huang et al. [4] and Tian et al. [5] considered the Shanmen Ag deposit to be a medium-temperature magmatic hydrothermal vein-type deposit, but Fu [6] and Wang [7] suggested that it is an epithermal deposit. Their studies have mainly focused on the geochronology of the host rocks, structural characteristics and isotopic geochemistry. But tests about ore-forming fluids such as fluid inclusions have not been done. The controversy of the genetic type of the deposit has seriously limited ore prospecting in the deep and peripheral parts of the mining area. In general, the key to reaching a consensus on ore genesis is the source and evolution of the ore-forming fluids and materials.

To determine the ore genesis of the Shanmen Ag deposit, we conducted a detailed study focusing on deposit geology, fluid inclusions from different stages of mineralization, $\mathrm{H}$ isotopes in water from fluid inclusions in ore-bearing quartz, $\mathrm{O}$ isotopes of the quartz, $\mathrm{S}$ and $\mathrm{Pb}$ isotopic compositions of sulfides. Using these data, we determined the nature, source and evolution of ore-forming fluids and metals in detail. Combined with the unpublished chronological data, this study can not only help us to determine the ore genetic type, but understand the mechanism of ore concentration, transportation and precipitation in detail as well.

\section{Regional Geology}

Since the Paleozoic era, NE China has experienced subduction and collision between the North China Plate and the Siberian Plate, subduction and closure of the Paleo-Asian Ocean Plate, and subduction of the Paleo-Pacific Plate [8-10], leading to an extremely complex tectonic setting with large-scale magmatism. In particular, the westward subduction of the Paleo-Pacific Plate resulted in the emergence of a large number of Mesozoic granites and volcanic rocks, which have close spatial, temporal and genetic relationships with many Mesozoic endogenetic metal deposits in NE China $[10,11]$.

The studied Siping area is located in the southern region of the Jilin Province and tectonically located in the continental margin of the southern margin of the Songnen Block and the northern margin of the North China Plate (Figure 1b). A large number of complexes on the continental margin have recorded the process of southward Paleozoic subduction and final closure of the Paleo-Asian Ocean Plate in the Late Permian to Early Triassic $[12,13]$. The exposed sedimentary rocks in the study area are composed of early Paleozoic volcano-sedimentary rocks, Mesozoic continental volcaniclastic rocks, and Quaternary clastic sediments. According to the emplacement ages, the intrusions in this area can be divided into three phases: (1) the early Paleozoic diorite with the age of 445-400 Ma; (2) the late Paleozoic granite and diorite with the age of 367-350 Ma; and (3) the Mesozoic granite with the age of 175-163 Ma [13-15] (Figure 1c). The structures in this area are dominated by NE-trending faults, consisting of three main faults and some secondary faults (Figure 1c). From west to east, the main faults are the Dehui-Siping Fault, Banlashanmen Fault, and Yitong-Yilan Fault, which divide the area into four secondary tectonic units: Songliao Interruption, Daheishan Horst, Yitong-Yilan Rift, and Liaoyuan Uplift [16]. The Shanmen Ag deposit is located in the Daheishan Horst in the western part of the Yitong-Yilan Fault. The Yitong-Yilan Fault and its secondary faults are the main ore-controlling structures. In addition to the Shanmen Ag deposit, other metal deposits such as the Sanjiazi scheelite deposit and Shanmen nickel deposit occur in the area. Studies have shown that their formation is related to the Mesozoic magmatism [17]. 


\section{Ore Deposit Geology}

The exposed sedimentary rocks in the Shanmen Ag deposit are mainly metamorphosed clastic rocks and carbonate rocks of the middle Ordovician Huangyingtun Formation, which have an overall strike of NNE direction and are consistent with regional tectonic structures (Figure 2a). Due to the influence of post-structural magmatism, the Huangyingtun Formation is mostly distributed in belt and island shapes in the eastern part of the mining area. Feng et al. [16] determined that the average content of silver in the Huangyingtun Formation is 10 times higher than the Clarke value [18], which is very beneficial to Ag enrichment and mineralization process. The types of intrusions include intermediate-acidic rocks such as monzonite, quartz diorite, biotite granite, and rhyolite and dykes such as diorite porphyry and lamprophyre. The monzonite and quartz diorite have a close spatial relationship with the Ag-Au mineralization, but the former has a relatively larger exposed area, hosting most of the ore bodies. Monzonites exhibit a medium- to fine-grained granitic texture and massive structure, and mainly contain quartz, plagioclase and potash feldspar. As closer to the ores, they started to alter and formed some muscovites. The structures in this area are dominated by ductile-brittle deformation and appear to have controlled fluid concentration and silver deposition. They mainly develop in a NNE direction, and can be divided into three stages: (1) NNE ductile shear zones control the overall directions of intrusions (Figure 3a). They reflect a trending direction of $\mathrm{N} 25^{\circ} \mathrm{E}$ to $\mathrm{N} 45^{\circ} \mathrm{E}$ and intrusions have shown extensive ductile deformation under the influence of the ductile shear zones. (2) Brittle fractures that superimposed on the ductile shear zones (Figure 3a); they crosscut intrusions and host most of the orebodies. As ore-controlled structures, these brittle fractures are closely associated with the formation of the Ag-rich quartz veins. (3) A small number of NW-trending faults that are post-ore-forming structures and developed after mineralization (Figure $3 b$ ). They crosscut both deformed intrusions and orebodies and do not have any remobilization effects.

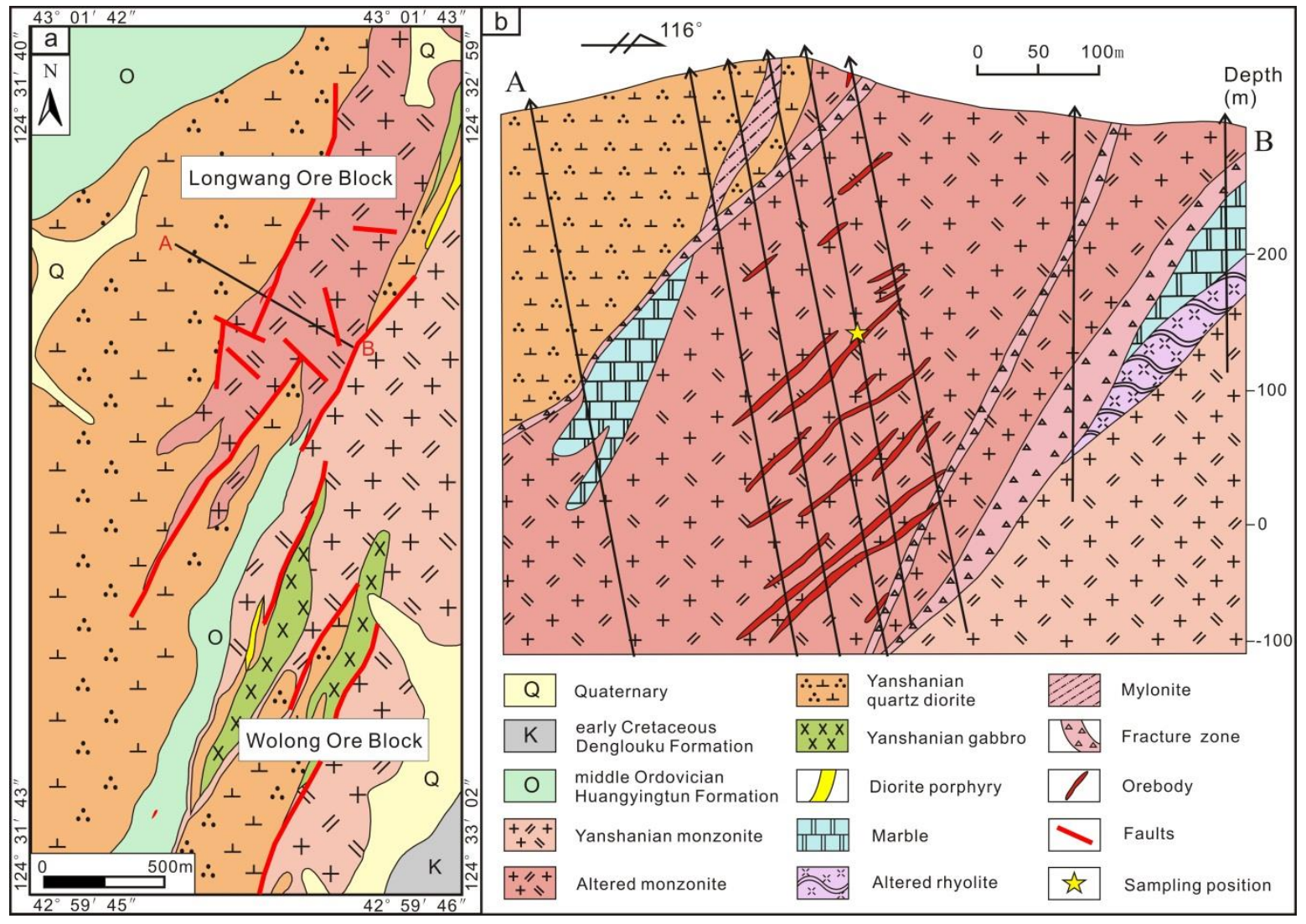

Figure 2. (a) Geological map of Wolong and Longwang ore blocks in the Shanmen Ag deposit; (b) geological section along the Number 44 exploration line of Longwang ore block. 

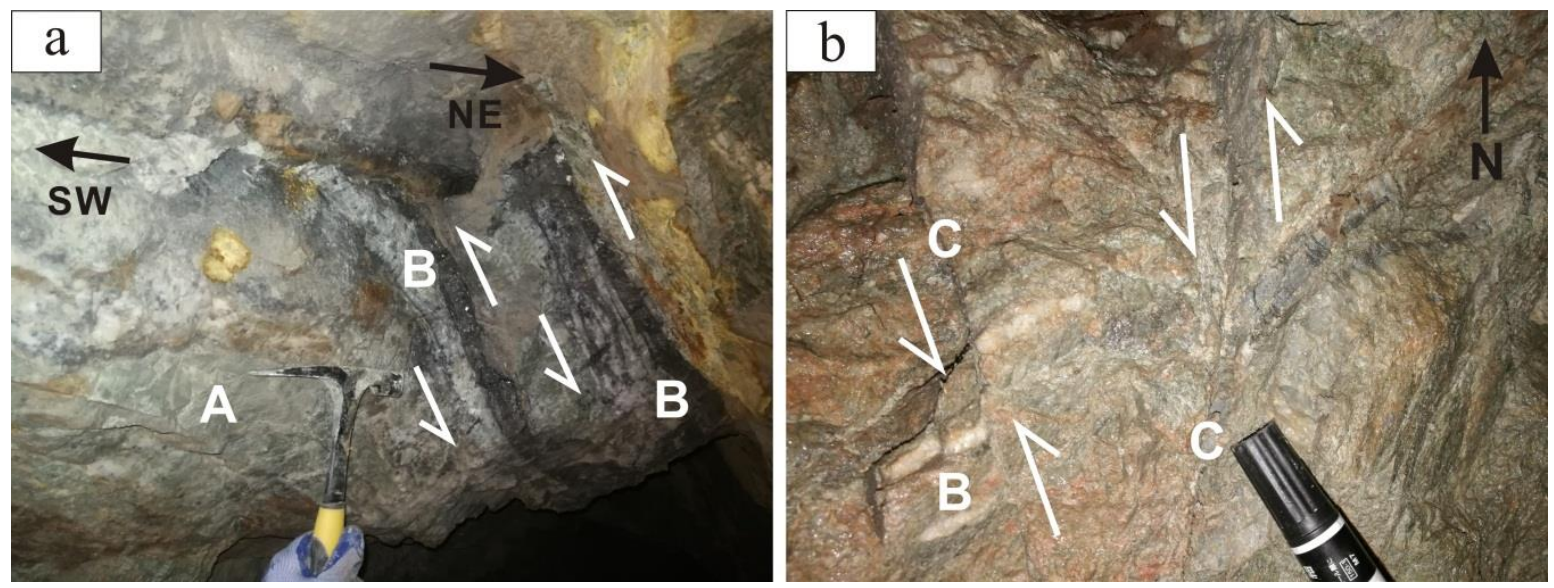

Figure 3. (a) Orebodies hosted in NE-trending brittle fractures crosscut deformed intrusions; (b) NW-trending post-ore-forming structures crosscut Ag-bearing quartz veins and the drag structure. A: deformed intrusions due to the reformation of ductile shear zones; B: brittle fractures hosting orebodies; C: post-ore-forming structures crosscutting orebodies.

The orebodies filled in the NNE-trending faults in the mining area and veins and veinlets are lenticular ( 5-200 m) and layered. They are mainly controlled by fractures in monzonite and their overall trend is consistent within the tectonic belt. In the Shanmen ore district, Wolong and Longwang ore blocks are the most important. The Wolong ore block, located in the middle of the mining area, hosts more than 10 proven ore bodies. Most of them are concealed-semi concealed orebodies. They dip NW at an angle of $20-60^{\circ}$ with greatly varied thickness and spread nearly parallel with fractures. The Longwang ore block, located in the northern part of the mining area, has a slightly smaller scale but higher grade. It includes 28 proven orebodies-all of which are concealed vein-type orebodies. They evidently fill in brittle fractures in the monzonite and their occurrence is similar to the orebodies in the Wolong ore block but with larger dip angles (Figure $2 b$ ).

The Ag-bearing ores are characterized by quartz veins or fractured altered rocks, among which the quartz vein type is dominant and has a relatively high Ag grade (Figure 6a,b). The dominant ore structures include veined, veinlet, disseminated, and banded structures (Figure $4 a-c)$, and the textures are mainly euhedral- to subhedral-granular (Figure 5a), replaced (Figure 5b,c), and exsolution (Figure $5 \mathrm{~d}, \mathrm{e}$ ) textures. The metallic minerals in the ore mainly include sulfides such as pyrite, galena, sphalerite, and chalcopyrite and silver-bearing minerals such as diaphorite (Figure 5f), argentite and native silver. The nonmetallic minerals include quartz, calcite, muscovite and chlorite. The types of wall rock alteration in the monzonite are mainly muscovitization (Figure 6c), chloritization (Figure 6d), silicification, sericitization (Figure 6e) and kaolinization. In the quartz diorite, these are mainly silicification, sericitization, and carbonation (Figure 6f). Note that some micas, such as muscovite and sericite, are clearly observed inside the monzonite and quartz veins, which has different morphology. Muscovite can be classified into two types via the crystallinity. Those with relatively good crystallinity mostly grow in monzonite with slight alterations, having apparent crystalline structure (Figure 6c), and are similar to greisen-like alteration. The others, with a fine-grained structure, are closely symbiosis with sericite and calcites near the ores. Sericites are spatially close to the ores and have microcrystalline structure (Figure 6e,f). Therefore, we consider that coarse-grained muscovite formed before or early in mineralization, whereas sericite were formed nearly simultaneously with silver mineralization. Field observations and petrography studies indicate that the silicification and sericitization occurred near ore minerals as well. 

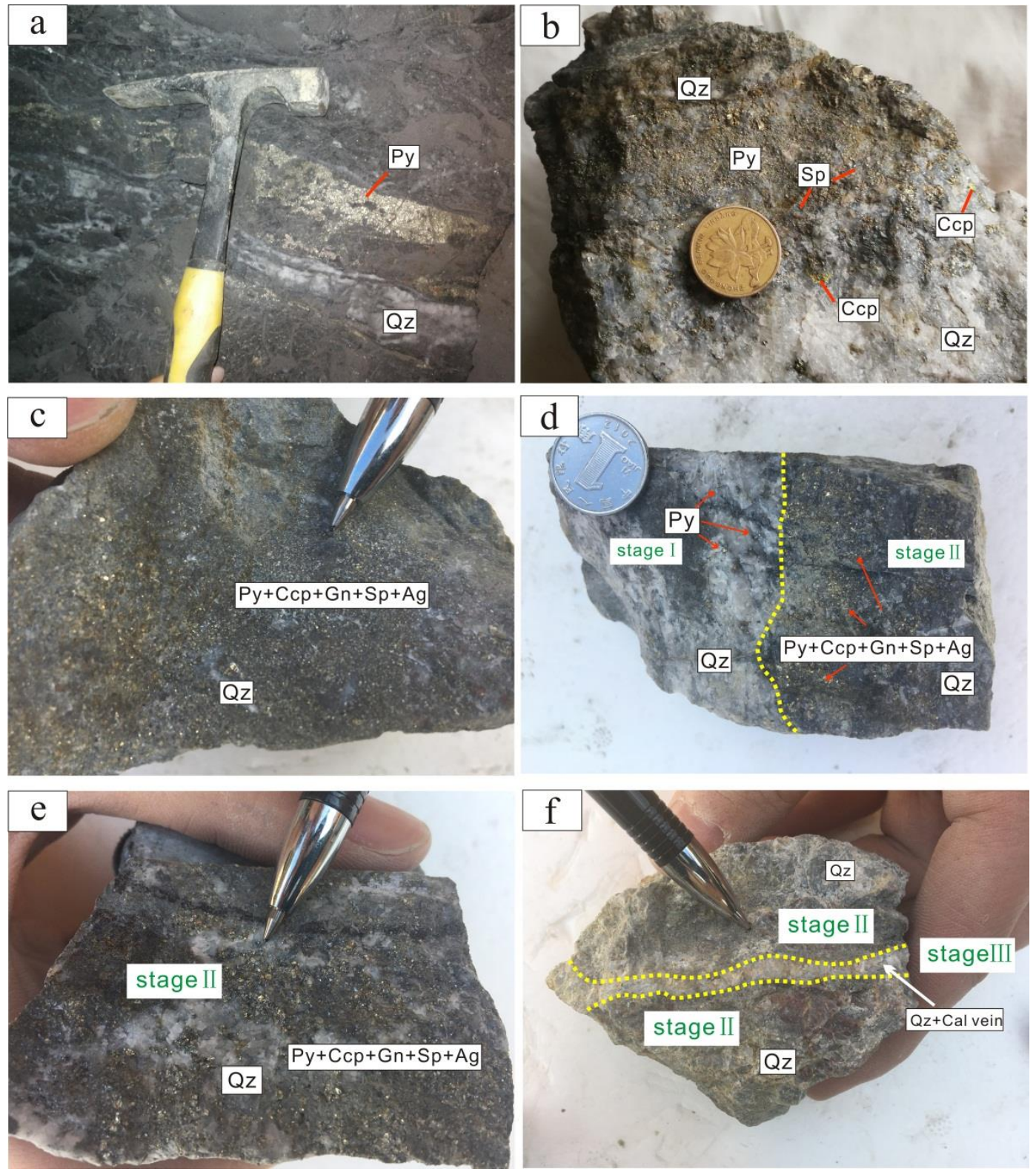

Figure 4. Ore types and characteristics. (a) Banding structure of pyrite-bearing ore; (b) disseminated ore structure consisting of pyrite, chalcopyrite and sphalerite; (c) densely disseminated polymetallic mineralization; (d) pyrite-quartz stage (Stage I) and quartz-silver-polymetallic sulfides stage (Stage II, main ore forming stage); (e) quartz-silver-polymetallic sulfides stage (Stage II,); (f) quartz-silver-polymetallic sulfides stage (Stage II) crosscut by the quartz-calcite veins in carbonate-quartz stage (Stage III); Py-pyrite; Ccp-chalcopyrite; Sp-sphalerite; Gn-galena; Ag—silver; Qz-quartz; Cal—calcite. 

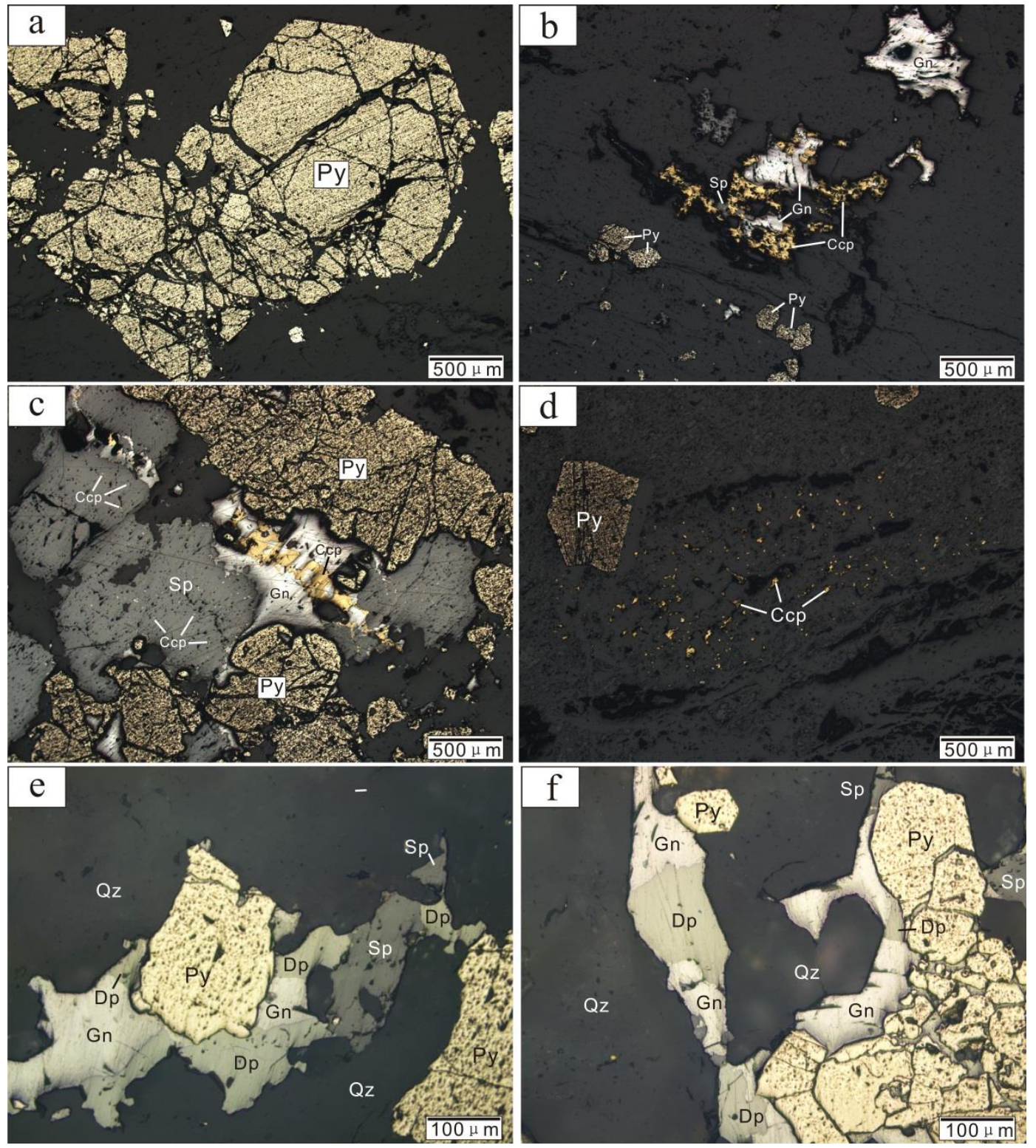

Figure 5. Photomicrographs showing the characteristics of ore composition. (a) Fragmented texture of euhedral- to subhedral-granular pyrite; (b) the sulfides assemblages in Stage II; (c) the sphalerite and chalcopyrite replaced by galena and the exsolution texture of later chalcopyrite; (d) disseminated chalcopyrite in quartz fractures (Stage II); (e) diaphorite in galena and sphalerite (Stage II); (f) diaphorite in galena (Stage II). Py—pyrite; Ccp—chalcopyrite; Sp—sphalerite; Gn—galena; Dp-diaphorite; Qz-quartz. 

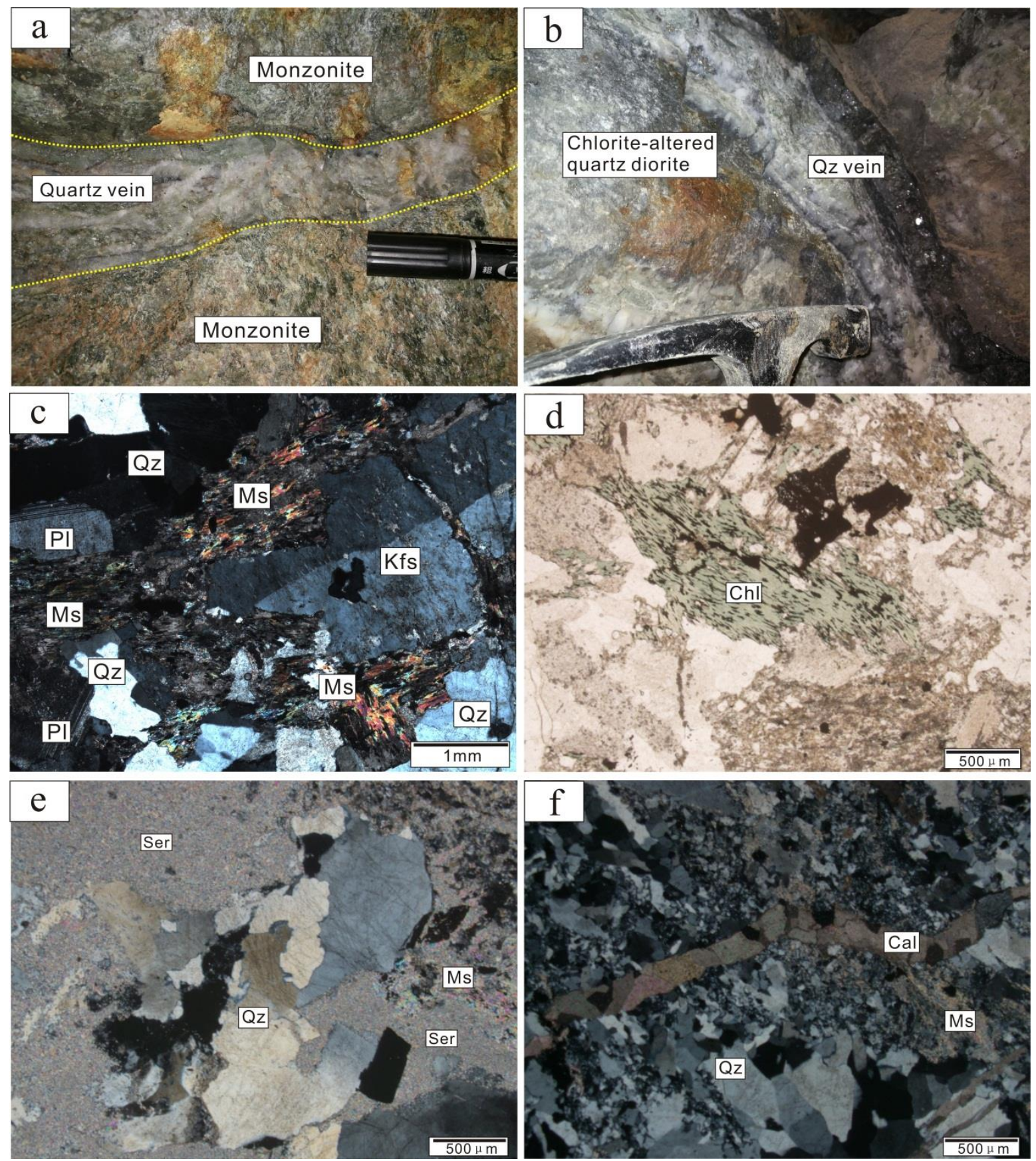

Figure 6. Field photos and photomicrographs showing the characteristics of wall rocks and alterations. (a) Quartz vein type ore body hosted in monzonite; (b) chlorite-altered quartz diorite crosscut by quartz vein-type orebody; (c) the coarse-grained muscovites in monzonite with slight alterations; (d) chloritization in phyllic-altered monzonite; (e) silicification, sericitization and muscovitization in Stage II; (f) silicification, carbonation and muscovitization in Stage III. Qz-quartz; Pl—plagioclase; Kfs—potash feldspar; Chl—chlorite; Ms—muscovite; Ser—sericite; Cal—calcite.

According to the mineral paragenetic associations, ore textures and structures, crosscutting relationships of minerals, and wall-rock alteration (Figure $4 \mathrm{~d}-\mathrm{f}$ ), the hydrothermal mineralization process can be divided into three stages:

Stage I (pyrite-quartz stage): This stage mainly produced the white ore-bearing quartz veins, and the sulfides in this stage mainly include euhedral- to subhedral-granular pyrite and a small amount of sphalerite and chalcopyrite. Silver mineralization is relatively weak, and alteration in orebodies and monzonite mainly comprises silicification and greisenization. 
Stage II (quartz-Ag-polymetallic-sulfides stage): The ore-bearing quartz has a grayish color (Figure 3e), and the metal sulfides in the order of mineral formation are pyrite, sphalerite, chalcopyrite and galena, along with diaphorite, argentite and natural silver. This is the major stage of precipitation of silver minerals. The alteration types associated with Ag mineralization mainly consist of silicification and sericitization.

Stage III (carbonate-quartz stage): Veins formed in this stage are mainly composed of white quartz and calcite, occasionally with pyrite and chalcopyrite. The sulfide content is low, and the main alteration types are chloritization and carbonation.

\section{Samples and Analytical Methods}

The samples used for fluid inclusion and H-O isotope studies were collected from the quartz vein-type ore in the Longwang ore block of the Shanmen Ag deposit. Samples SM-6 and SM-14 were collected from the number 6 orebody in the number 48 exploration line, which are pyrite-quartz veins formed in Stage 1. Samples SM-9, SM-10, SM-20, and SM-23 were taken from the number 6 ore body in the number 44 exploration line, which is the polymetallic-sulfides grayish quartz veins formed in Stage 2. Sample SM-16 was chosen from the number 3 orebody in the number 44 exploration line on the surface, which is the white carbonate-quartz veins in Stage 3. Pure pyrite, sphalerite, and galena samples for $\mathrm{S}$ and $\mathrm{Pb}$ isotope studies were chosen from high-grade $\mathrm{Ag}$ polymetallic sulfide ore samples from the number 6 orebody of the number 44 exploration line in the Longwang ore block, SM-21 and SM-23, which formed in the main ore-forming stage (Table 1).

Table 1. Sampling position of the Shanmen Ag deposit.

\begin{tabular}{ccccc}
\hline Sample Number & Sample Type & Minerals & $\begin{array}{c}\text { Orebody } \\
\text { Number }\end{array}$ & $\begin{array}{c}\text { Exploration Line } \\
\text { Number }\end{array}$ \\
\hline SM-6 & Stage 1 Pyrite-quartz veins & Quartz & 6 & 48 \\
SM-14 & Quartz & 6 & 48 \\
\hline SM-9 & Stage 2 Polymetallic-sulfides & Quartz & 6 & 44 \\
SM-10 & grayish quartz veins & Quartz & 6 & 44 \\
SM-20 & & Pyrite & 6 & 44 \\
SM-21 & & Sphalerite, & 6 & 44 \\
SM-23 & galena & & 44 \\
\hline SM-16 & Stage 3 Carbonate-quartz veins & Quartz & 3 & 44 \\
\hline
\end{tabular}

\subsection{Fluid Inclusion Analytical Methods}

Quartz veins closely associated with the ores in each mineralization stage were selected to make doubly polished fluid inclusion thin sections with a thickness of about $0.2 \mathrm{~mm}$. Then, they were measured in the Fluid Inclusion Laboratory of the Chinese Academy of Geological Sciences, Beijing, using a Linkam THMS G600 micro hot-cold stage to carry out petrographic observation and microthermometry analysis of inclusions within a temperature range of -196 to $+600^{\circ} \mathrm{C}$ and with an accuracy of $+/-0.1^{\circ} \mathrm{C}$. During the test, the temperature was first cooled to $-100{ }^{\circ} \mathrm{C}$ and the sample was allowed to stand for $1 \mathrm{~min}$; then, the temperature was gradually increased. The temperature increase rate was $2{ }^{\circ} \mathrm{C} / \mathrm{min}$ near the ice melting temperature and $5^{\circ} \mathrm{C} / \mathrm{min}$ when the temperature was close to the uniform temperature. A Renishaw System-2000 Raman spectrometer was used to carry out laser Raman spectroscopy analysis of the gas phase composition. The laser had an excitation wavelength of $514.53 \mathrm{~nm}$, power of $20 \mathrm{~mW}$, beam spot of $1 \mu \mathrm{m}$, and spectral resolution of $1-2 \mathrm{~cm}^{-1}$.

For aqueous two-phase inclusions, the salinity can be calculated according to the measured ice melting temperature using the equation provided by Potter et al. [19], and the fluid density can be calculated by the formula provided by Liu and Duan [20]. For $\mathrm{CO}_{2}$-bearing multi-phase inclusions, the salinity can be calculated from the melting temperature of solid $\mathrm{CO}_{2}$ using the equation provided by 
Bozzo et al. [21], and the fluid density can be estimated according to the formula provided by Touret and Bottinga [22].

\subsection{H-O Isotope Analysis}

The quartz samples in all three mineralization stages for $\mathrm{H}-\mathrm{O}$ isotope tests were collected together with those in use of fluid inclusions. Quartz was handpicked under a binocular microscope to ensure a purity of more than $98 \%$. The H-O isotope tests were completed at the Research Institute of Uranium Geology, Beijing, using a MAT-253 mass spectrometer. O isotope compositions were determined by the conventional $\mathrm{BrF}_{5}$ method. $\mathrm{H}$ isotopic compositions were determined by decrepitation of fluid inclusions in quartz samples. The $\mathrm{CO}_{2}$ was separated from $\mathrm{H}_{2} \mathrm{O}$ by using a liquid-nitrogen cold trap system and the $\mathrm{H}_{2} \mathrm{O}$ was reduced to $\mathrm{H}_{2}$ by passing it over a uranium metal-bearing tube. The test values were based on the SMOW international standard, with analytical precisions of $\pm 2 \%$ o for $\delta \mathrm{D}$ and $\pm 0.2 \%$ o for $\delta^{18} \mathrm{O}$. The $\delta \mathrm{D}$ values can be determined directly, but the $\delta^{18} \mathrm{O}_{\mathrm{H} 2 \mathrm{O}}$ values need to be calculated using the equation $1000 \ln \alpha=3.38 \times 10^{6} / \mathrm{T}^{2}-3.40$ [23] based on the average homogenization temperatures of fluid inclusions and the oxygen isotope fractionation coefficient of the quartz-water system.

\section{3. $\mathrm{S}$ and $\mathrm{Pb}$ Isotope Analysis}

The $\mathrm{S}$ and $\mathrm{Pb}$ isotope tests of sulfides were completed at the Research Institute of Uranium Geology, Beijing as well. The sulfides were pulverized to 200 mesh before the test and handpicked under a binocular microscope to ensure a purity of more than $95 \%$. In the $\mathrm{S}$ isotope composition analysis, the sulfides and $\mathrm{Cu}_{2} \mathrm{O}$ were heated under vacuum to form sulfur dioxide, which was then analyzed by a Delta V Plus gas isotope mass spectrometer. $\delta^{34} \mathrm{~S}$ values were reported in V-CDT (Vienna standard troilite in Canyon Diablo meteorite) standard, and the test accuracy was about $\pm 0.2 \%$ o. For the $\mathrm{Pb}$ isotope ratio analysis, the sulfide samples were first leached with hot acid and then tested on an Isoprobe-T hot-surface ionization mass spectrometer using the standard sample NBS981. The Pb isotope test values are ${ }^{208} \mathrm{~Pb} /{ }^{206} \mathrm{~Pb}=2.1681 \pm 0.0008,{ }^{207} \mathrm{~Pb} /{ }^{206} \mathrm{~Pb}=0.91464 \pm 0.00033$, and ${ }^{204} \mathrm{~Pb} /{ }^{206} \mathrm{~Pb}=0.059042 \pm 0.000037$, respectively, and the test accuracy was higher than $0.08 \%$.

\section{Results}

\subsection{Fluid Inclusions}

\subsubsection{Fluid Inclusion Types}

Petrographic studies indicated that fluid inclusions are abundant in the ore-bearing quartz veins from all three mineralization stages at the Shanmen Ag deposit. We classified primary and secondary inclusions by their shapes and distribution. The former is distributed independently or in clusters and hosted in intragranular quartz crystals, whereas, the latter aligned along micro-fractures in transgranular trails [24]. The larger inclusions have a long axis of about 15-20 $\mu \mathrm{m}$, and the smaller ones have a long axis of less than $2 \mu \mathrm{m}$. In the smaller inclusions, it was difficult to observe phase changes during the heating experiments. According to their compositions, phase portions, and ratios at room temperature, primary fluid inclusions were grouped into five types: L-type (liquid-rich two-phase inclusions), V-type (vapor-rich two-phase inclusions), C-type $\left(\mathrm{CO}_{2}\right.$-bearing aqueous inclusions), PL-type (pure liquid inclusions), and PC-type (pure $\mathrm{CO}_{2}$ inclusions). Because the PL-type and PC-type inclusions are rare and most of them are too small to conduct microthermometry, we only measured the other three types of inclusions. These are described below.

$\mathrm{CO}_{2}$-bearing aqueous inclusions (C-type): These inclusions can be divided further into two subtypes: two-phase inclusions consisting of liquid water and vapor $\mathrm{CO}_{2}$ and three-phase inclusions consisting of liquid water, vapor $\mathrm{CO}_{2}$, and liquid $\mathrm{CO}_{2}$. The latter is more abundant. Most of the inclusions are dominated by the $\mathrm{CO}_{2}$ phase, have ellipsoidal or subcircular shapes, and are between 4 
to $10 \mu \mathrm{m}$ in diameter. The $\mathrm{CO}_{2}$ phase was homogenized first during heating and finally homogenized to liquid phase or burst. This type of inclusion can only be observed in Stage I (Figure 7a-c).

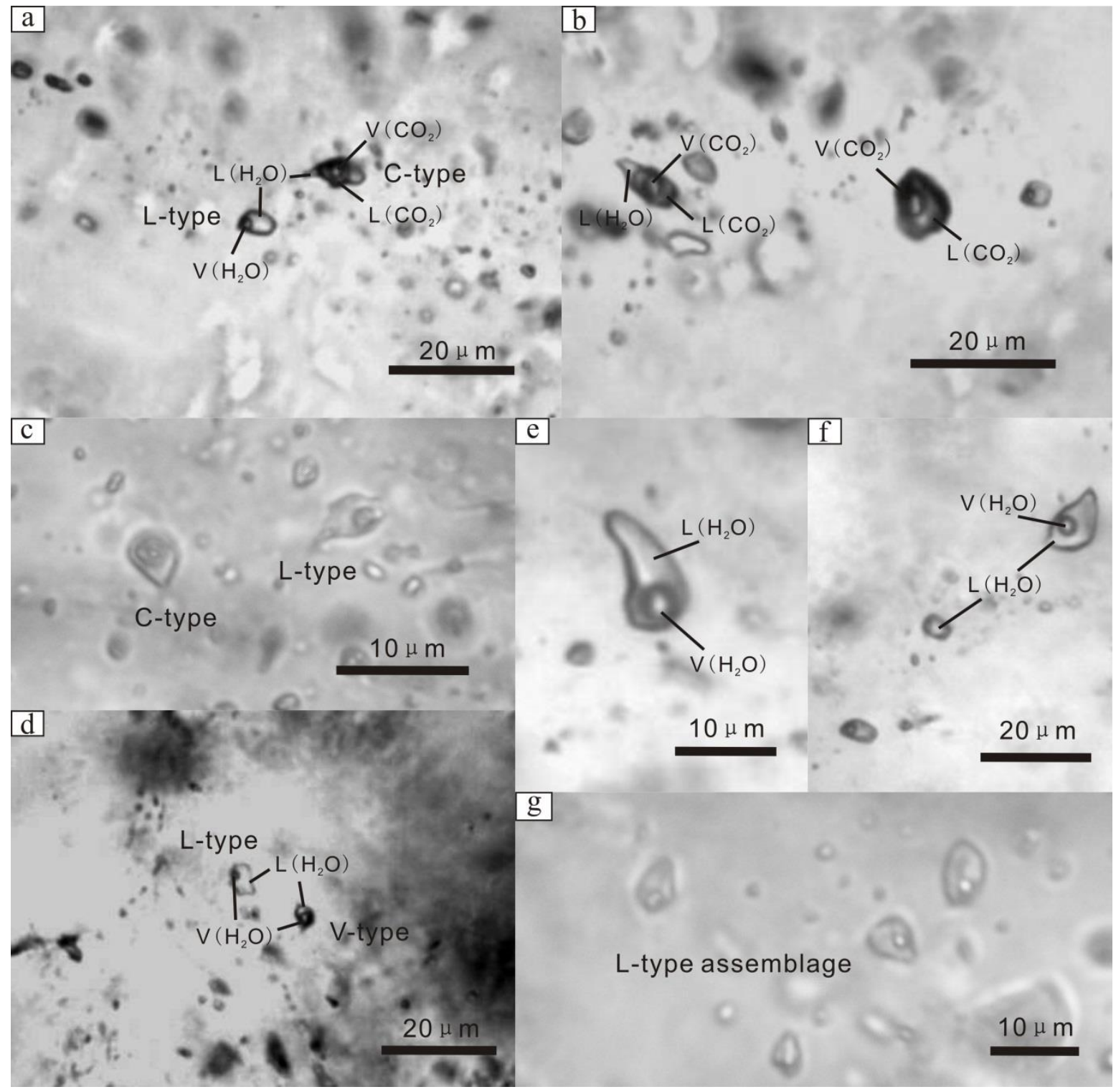

Figure 7. Photomicrographs of typical fluid inclusions in the Shanmen Ag deposit. (a) $\mathrm{CO}_{2}$ aqueous (C-type) fluid inclusions coexisting with liquid-rich (L-type) fluid inclusions in Stage I quartz; (b) C-type fluid inclusions coexisting with pure $\mathrm{CO}_{2}$ (PC-type) fluid inclusions in Stage I quartz; (c) C-type fluid inclusions coexisting with L-type fluid inclusions in Stage I quartz; (d) L-type fluid inclusions coexisting with vapor-rich (V-type) fluid inclusions in Stage II quartz; (e) L-type fluid inclusions in Stage II quartz; (f) L-type and V-type fluid inclusions in Stage II quartz; (g) L-type fluid inclusion assemblage in Stage III quartz.

Liquid-rich inclusions (L-type): These consist of liquid water and relatively small vapor bubbles and have vapor-liquid ratios of $15 \%$ to $40 \%$. They have subcircular or irregular shapes and sizes of 5-10 $\mu \mathrm{m}$. This type of inclusion is abundant in the quartz veins and is homogenized to the liquid phase during heating. They can be observed in each stage (Figure 7a,e-g).

Vapor-rich inclusions (V-type): This type of inclusion is composed of liquid water and vapor bubbles in large volumes. Their vapor-liquid ratios can be $60 \%$ or more. They have ellipsoidal, irregular shapes and sizes between 5 and $10 \mu \mathrm{m}$. These inclusions have smaller quantity and are often 
distributed in groups with L-type inclusions. They homogenize to the vapor phase during heating, and mainly occur in Stages II and III (Figure 7d).

\subsubsection{Microthermometry Results}

We chose representative fluid inclusions from the three mineralization stages to conduct microthermometry and obtained a total of 162 measurements, as shown in Table 2. Homogenization temperatures and salinities calculated according to the relevant formulas are shown in Figure 8.

Table 2. The microthermometric results of fluid inclusions from the Shanmen Ag deposit.

\begin{tabular}{|c|c|c|c|c|c|c|c|c|}
\hline Stage & Type & Number & $\begin{array}{l}\text { Tice }^{1} \\
\left({ }^{\circ} \mathrm{C}\right)\end{array}$ & $\begin{array}{l}\text { Tcla }^{2} \\
\left({ }^{\circ} \mathrm{C}\right)\end{array}$ & $\begin{array}{l}\mathrm{Te}^{3} \\
\left({ }^{\circ} \mathrm{C}\right)\end{array}$ & $\begin{array}{l}\mathrm{Th}^{4} \\
\left({ }^{\circ} \mathrm{C}\right)\end{array}$ & $\begin{array}{c}\text { Salinity (wt.\% } \\
\mathrm{NaCl} \text { Equivalent) }\end{array}$ & $\begin{array}{l}\text { Density } \\
\left(\mathrm{g} / \mathrm{cm}^{3}\right)\end{array}$ \\
\hline \multirow{3}{*}{ Stage I } & L-type & 27 & \multirow{3}{*}{$\begin{array}{c}-8.3 \text { to } \\
-2.5 \\
-5.3 \text { to } \\
-3.9\end{array}$} & & & $\begin{array}{c}191.8 \text { to } \\
390.7\end{array}$ & 4.2 to 12.1 & 0.64 to 0.96 \\
\hline & V-type & 4 & & & & $\begin{array}{c}273.3 \text { to } \\
327.5\end{array}$ & 6.3 to 8.3 & 0.75 to 0.82 \\
\hline & C-type & 8 & & $\begin{array}{l}6.9 \text { to } \\
9.2\end{array}$ & $\begin{array}{c}23.4 \text { to } \\
31.1\end{array}$ & $\begin{array}{c}272.2 \text { to } \\
412.5\end{array}$ & 1.6 to 5.9 & 0.55 to 0.74 \\
\hline \multirow[t]{2}{*}{ Stage II } & L-type & 77 & $\begin{array}{c}-5.8 \text { to } \\
-0.8\end{array}$ & & & $\begin{array}{c}124.1 \text { to } \\
313.3\end{array}$ & 1.4 to 8.9 & 0.73 to 0.98 \\
\hline & V-type & 13 & $\begin{array}{c}-4.8 \text { to } \\
-0.8\end{array}$ & & & $\begin{array}{c}153.4 \text { to } \\
272.4\end{array}$ & 1.4 to 7.6 & 0.81 to 0.97 \\
\hline $\begin{array}{l}\text { Stage } \\
\text { III }\end{array}$ & L-type & 33 & $\begin{array}{c}-3.6 \text { to } \\
-0.2\end{array}$ & & & $\begin{array}{c}128.6 \text { to } \\
224\end{array}$ & 0.4 to 5.8 & 0.90 to 0.96 \\
\hline
\end{tabular}

Note: ${ }^{1}$ ice melting temperature; ${ }^{2} \mathrm{CO}_{2}$-clathrate dissociation temperature; ${ }^{3} \mathrm{CO}_{2}$-eutectic temperatures; ${ }^{4}$ total homogenization temperature. 

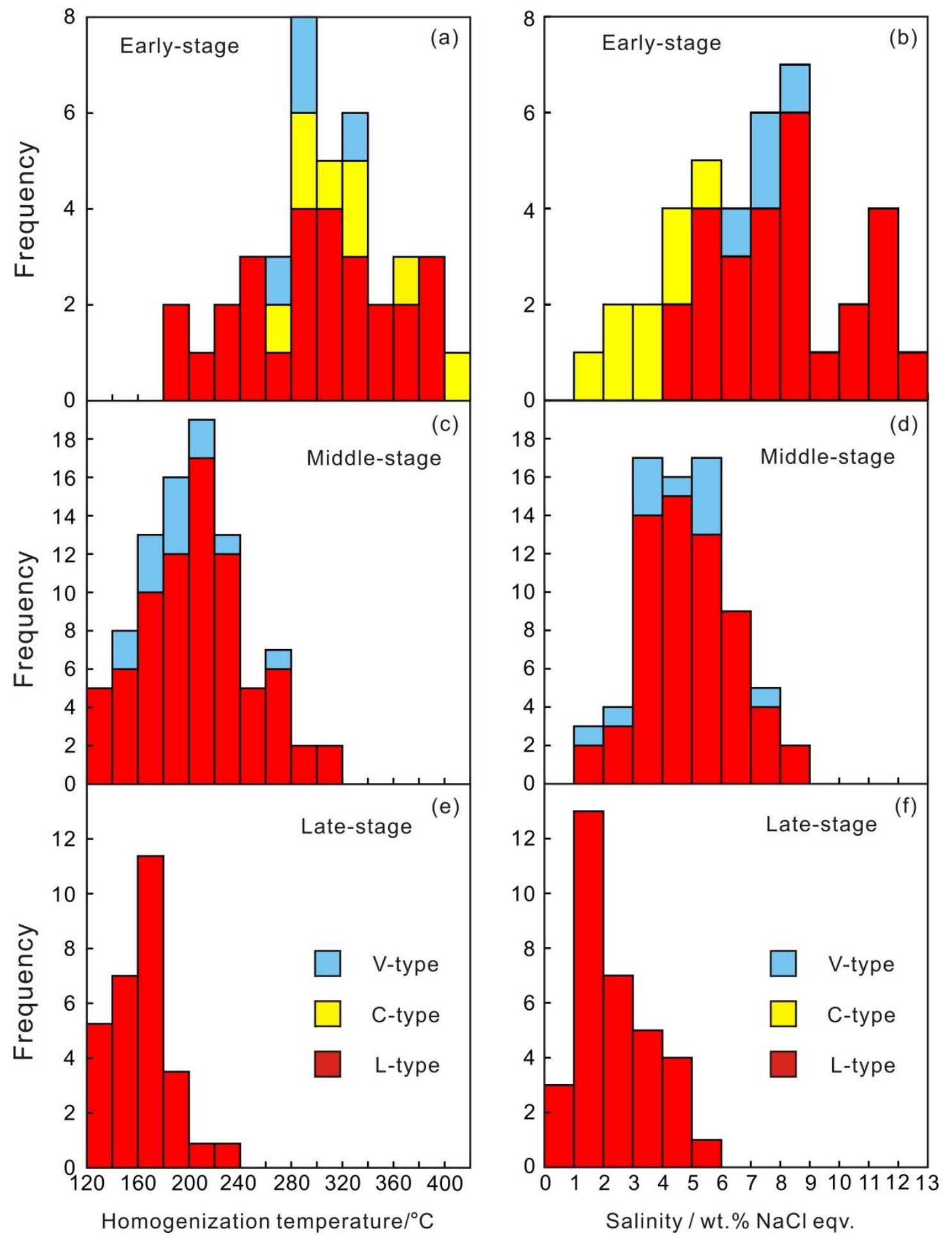

Figure 8. (a-f) Histograms of total homogenization temperatures (Th) and salinities of fluid inclusions from each of the mineralization stages.

Stage I (early-stage) quartz veins contain mainly L-, V-, and C-type inclusions with a few PC-type inclusions. The L-type inclusions homogenized at a temperature between 191.8 and $390.7^{\circ} \mathrm{C}$, with an average of $299.3{ }^{\circ} \mathrm{C}(\mathrm{n}=27)$. The ice melting temperature was between -8.3 and $-2.5^{\circ} \mathrm{C}$, and the calculated salinity range was between 4.2 and $12.1 \mathrm{wt} \% \mathrm{NaCl}$ equivalent They all homogenized to the liquid phase, and the estimated fluid density was $0.63-0.96 \mathrm{~g} / \mathrm{cm}^{3}$. The number of V-type inclusions was smaller, and the homogenization temperature was $327.5-273.3^{\circ} \mathrm{C}$ (average $=343{ }^{\circ} \mathrm{C}, \mathrm{n}=11$ ). 
All of these homogenized to the vapor phase. The ice melting temperature was between -5.9 and $-5.3{ }^{\circ} \mathrm{C}$, which corresponds to salinities between 6.3 and $8.3 \mathrm{wt} \% \mathrm{NaCl}$ equivalent, and the fluid density was approximately $0.63-0.96 \mathrm{~g} / \mathrm{cm}^{3}$. The melting temperature of solid $\mathrm{CO}_{2}$ in the C-type inclusions was -57.5 to $-56.8^{\circ} \mathrm{C}$, slightly lower than that of pure solid $\mathrm{CO}_{2}\left(-56.6^{\circ} \mathrm{C}\right)$, which indicates the existence of a few other volatiles in the $\mathrm{CO}_{2}$ phase. The gas $\mathrm{CO}_{2}$ phase homogenized to the liquid phase with increasing temperature (ranging from 23.4 to $31.1^{\circ} \mathrm{C}$ ). Then, it homogenized to a $\mathrm{CO}_{2}$ phase at a temperature of $412.5-272.2^{\circ} \mathrm{C}$, with an average of $319.7^{\circ} \mathrm{C}(\mathrm{n}=8)$. A small number eventually burst with increasing temperature. The salinity was $1.6-5.9 \mathrm{wt} \% \mathrm{NaCl}$ equivalent, and the fluid density was $0.55-0.74 \mathrm{~g} / \mathrm{cm}^{3}$.

Stage II (middle-stage) quartz veins contain mainly L-type and V-type inclusions, with no C-type, indicating that $\mathrm{CO}_{2}$ was released at this stage. The L-type inclusions homogenized to liquid at a temperature between 124.1 and $313.3^{\circ} \mathrm{C}$, peaking at $240-160^{\circ} \mathrm{C}$, with an average of $207.4^{\circ} \mathrm{C}(\mathrm{n}=77)$. The ice melting temperature was between -5.8 and $-0.8^{\circ} \mathrm{C}$, and the calculated salinity range was between 1.4 and $8.9 \mathrm{wt} \% \mathrm{NaCl}$ equivalent. The estimated fluid density was $0.73-0.98 \mathrm{~g} / \mathrm{cm}^{3}$. The V-type inclusions homogenized to vapor at a temperature between 153.4 and $272.4^{\circ} \mathrm{C}$, with an average of $194.3^{\circ} \mathrm{C}(\mathrm{n}=13)$. The ice melting temperature was between -4.8 and $-0.8{ }^{\circ} \mathrm{C}$, which corresponds to salinities between 1.4 and $7.6 \mathrm{wt} \% \mathrm{NaCl}$ equivalent, and the fluid density was approximately $0.81-0.97 \mathrm{~g} / \mathrm{cm}^{3}$.

In Stage III (late-stage), only L-type and a small number of PL-type inclusions were observed. The L-type inclusions homogenized entirely to liquid at temperatures ranging from 128.6 to $224.0^{\circ} \mathrm{C}$, with an average of $162.2^{\circ} \mathrm{C}(\mathrm{n}=33)$. The ice melting temperature was between -3.6 and $-0.2{ }^{\circ} \mathrm{C}$, which corresponds to salinities between 0.4 and $5.8 \mathrm{wt} \% \mathrm{NaCl}$ equivalent, and the fluid density was approximately $0.90-0.96 \mathrm{~g} / \mathrm{cm}^{3}$.

\subsubsection{Laser Raman Spectroscopy}

We selected different types of fluid inclusions from the first two stages for laser Raman spectroscopy analysis to determine their gas components. The results showed that only the $\mathrm{CO}_{2}$ component was detected in the C-type inclusions in the early stage (Figure 9a,b), with peak values of 1281, 1384, and $1386 \mathrm{~cm}^{-1}$, and that the vapor phase components in the L-type and V-type inclusions were mainly $\mathrm{H}_{2} \mathrm{O}$ (Figure 9c,d). 

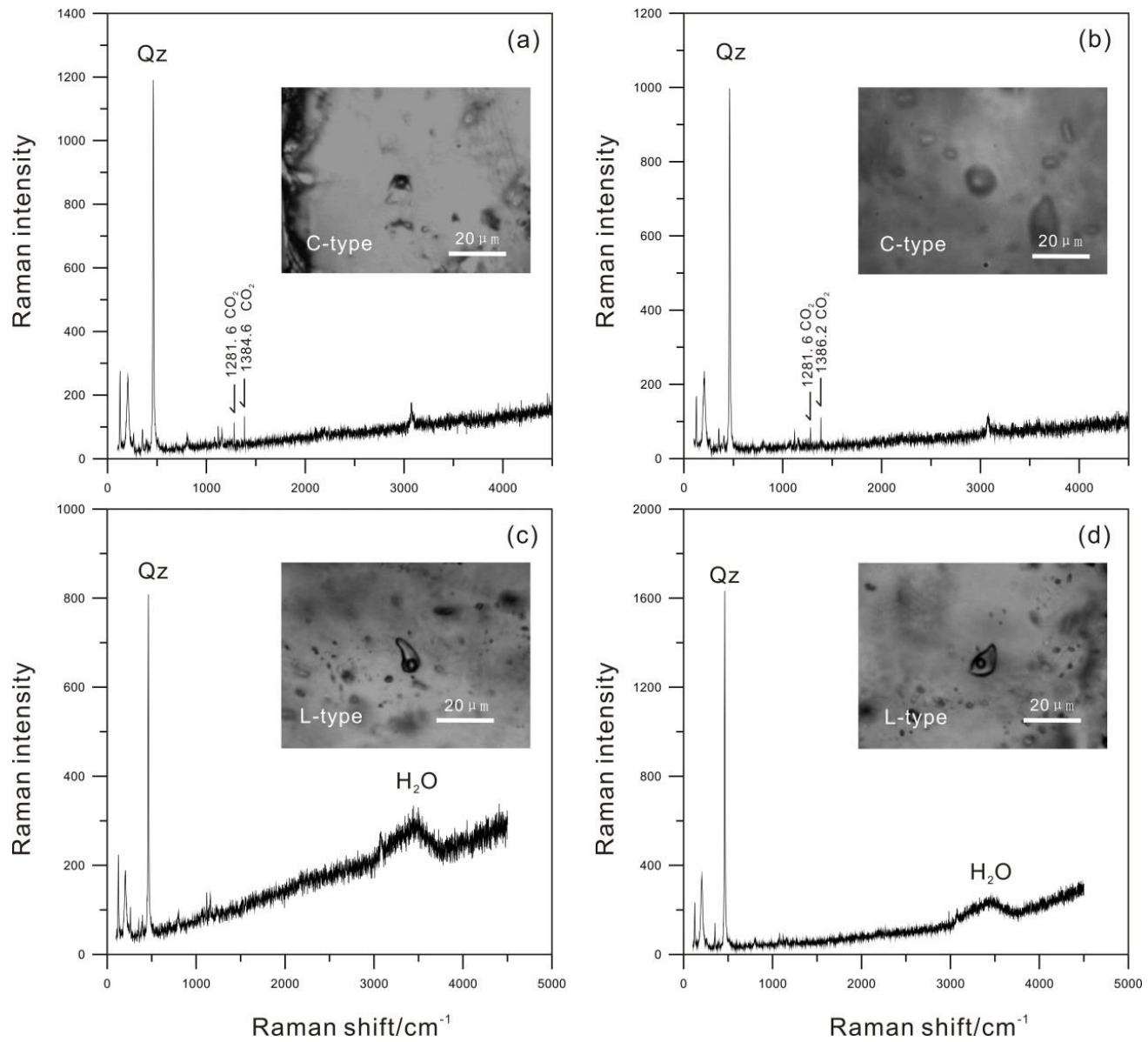

Figure 9. Representative Laser Raman spectra of fluid inclusions in the Shanmen Ag deposit. $(\mathbf{a}, \mathbf{b})$ Spectrum for C-type fluid inclusions in early-stage showing the contents of $\mathrm{CO}_{2} ;(\mathbf{c}, \mathbf{d})$ spectrum for L-type fluid inclusions in middle-stage.

\subsection{H-O Isotopes}

In this study, 12 samples spanning all three mineralization stages were analyzed. The data are shown in Table 3. The ranges of measured $\delta^{18} \mathrm{O}_{\mathrm{V}-\mathrm{SMOW}}$ values of quartz from Stage I to Stage III are 14.1 to $14.5 \%$ o, 11.7 to $13.6 \%$, and 10.8 to $11.5 \%$ o, respectively, and showed a slight descending trend. Using the quartz-water equilibrium function [23] and the homogenization temperature of the inclusion, we calculated the range of $\delta^{18} \mathrm{O}_{\mathrm{H} 2 \mathrm{O}}$ from Stage I to III as 7.7 to $8.1 \%$, 0.3 to $2.2 \%$, and -3.7 to $-3.0 \%$, respectively. The range of $\delta \mathrm{D}$ values measured directly on fluid inclusions from Stage I to III was -106 to $-103 \%$ o, -113 to $-105 \%$, and -107 to $-105 \%$, respectively (Figure 10 ).

Table 3. The H-O isotope analytical results of quartz veins from the Shanmen Ag deposit.

\begin{tabular}{|c|c|c|c|c|c|c|}
\hline Sample Number & Stage & Sample Type & $\operatorname{Th}\left({ }^{\circ} \mathrm{C}\right)$ & $\mathcal{\delta}^{18} \mathrm{O}(\% \mathrm{o})$ & $\delta^{18} \mathrm{O}_{\mathrm{H} 2 \mathrm{O}}(\%$ o $)$ & $\Delta d(\%)$ \\
\hline SM-14-1 & \multirow{3}{*}{ Stage I } & \multirow{3}{*}{$\begin{array}{l}\text { Poor-sulfide } \\
\text { quartz veins }\end{array}$} & 313 & 14.1 & 7.7 & -104 \\
\hline SM-14-2 & & & 313 & 14.5 & 8.1 & -106 \\
\hline SM-14-3 & & & 313 & 14.4 & 8.0 & -103 \\
\hline SM-23-1 & \multirow{6}{*}{ Stage II } & \multirow{6}{*}{$\begin{array}{l}\text { Sulfide-bearing } \\
\text { quartz veins }\end{array}$} & 205 & 13.6 & 2.2 & -108 \\
\hline SM-23-2 & & & 205 & 11.7 & 0.3 & -106 \\
\hline SM-23-3 & & & 205 & 12.8 & 1.4 & -106 \\
\hline SM-20-1 & & & 205 & 12.7 & 1.3 & -105 \\
\hline SM-20-2 & & & 205 & 12.9 & 1.5 & -105 \\
\hline SM-20-3 & & & 205 & 13.4 & 2.0 & -113 \\
\hline SM-16-1 & \multirow{3}{*}{ Stage III } & \multirow{3}{*}{ Quartz veins } & 162 & 10.8 & -3.7 & -105 \\
\hline SM-16-2 & & & 162 & 11.2 & -3.3 & -105 \\
\hline SM-16-3 & & & 162 & 11.5 & -3.0 & -107 \\
\hline
\end{tabular}




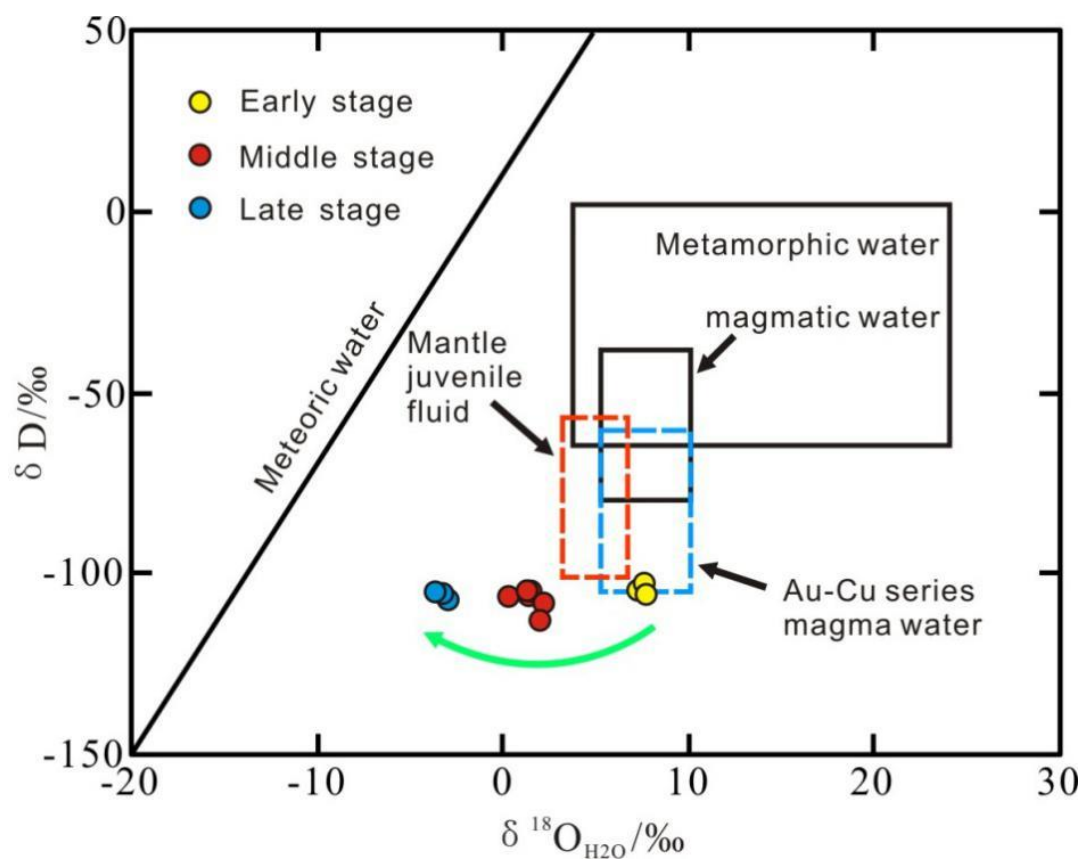

Figure 10. The relational diagram of hydrogen and oxygen isotopic compositions of the ore fluids for the Shanmen Ag deposit. The magmatic, metamorphic water boxes and meteoric water line are from Taylor [25]. The mantle juvenile fluid box is from Craig and Lupton [26]. The Au-Cu series magmatic water box is from Zhang et al. [27].

\section{3. $\mathrm{S}$ and $\mathrm{Pb}$ Isotopes}

The results of the $S$ isotope study supplemented by data from the previous literature [28] are shown in Table 4 . The $\delta^{34} \mathrm{~S}_{\mathrm{V}-\mathrm{CDT}}$ values of pyrite, sphalerite, and galena in early- and middle-stages ranged from -11.4 to $+1.8 \%$, with a large distribution range, indicating that the sulfur in the minerals most likely has multiple sources [29] (Figure 11). The $\delta^{34} S$ values of the two pyrite samples in the early stage were +0.4 and $+0.3 \%$, respectively, which are similar to the $\delta^{34} S$ value of pyrite in monzonite $\left(-1.9\right.$ to $+0.5 \%$ o) [28]. The $\delta^{34} \mathrm{~S}$ values of pyrite, sphalerite, and galena hosted in the middle stage were -4.6 to $+1.8 \%$ o (average of $-1.5 \%$ o), -8.7 to $+1.2 \%$ o (average of $-3.9 \%$ o), and -11.4 to $-2.7 \%$ o (average of $-8.2 \%$ ), respectively, in accordance with the order of distribution of $S$ isotope values under equilibrium conditions $\left(\delta^{34} \mathrm{~S}_{\mathrm{Py}}>\delta^{34} \mathrm{~S}_{\mathrm{Sp}}>\delta^{34} \mathrm{~S}_{\mathrm{Gn}}\right)$, indicating that the minerals were the products of the same period of mineralization $[30,31]$.

Table 4. The S isotope compositions of sulfides from the Shanmen Ag deposit.

\begin{tabular}{|c|c|c|c|c|c|}
\hline $\begin{array}{l}\text { Sample } \\
\text { Number }\end{array}$ & Sample Type & Minerals & $\delta^{34} S(\% o)$ & Mean & References \\
\hline SM-21-1 & \multirow{2}{*}{$\begin{array}{l}\text { Early-stage } \\
\text { lean ore }\end{array}$} & Pyrite & 0.4 & & \multirow{4}{*}{ This study } \\
\hline SM-21-2 & & Pyrite & 0.3 & & \\
\hline SM-23-1 & \multirow{2}{*}{ Block Ag ores } & Sphalerite & -0.4 & & \\
\hline SM-23-2 & & Galena & -9.4 & & \\
\hline- & Ore and & Pyrite & -4.6 to 1.8 & -1.5 & \multirow{5}{*}{ [28] } \\
\hline- & mineralization & Sphalerite & -8.7 to 1.2 & -3.9 & \\
\hline- & zone & Galena & -11.4 to -2.7 & -8.2 & \\
\hline- & Monzonite & Pyrite & -1.9 to 0.5 & -0.8 & \\
\hline- & Marble & Marble & -30.3 to -1.9 & - & \\
\hline
\end{tabular}



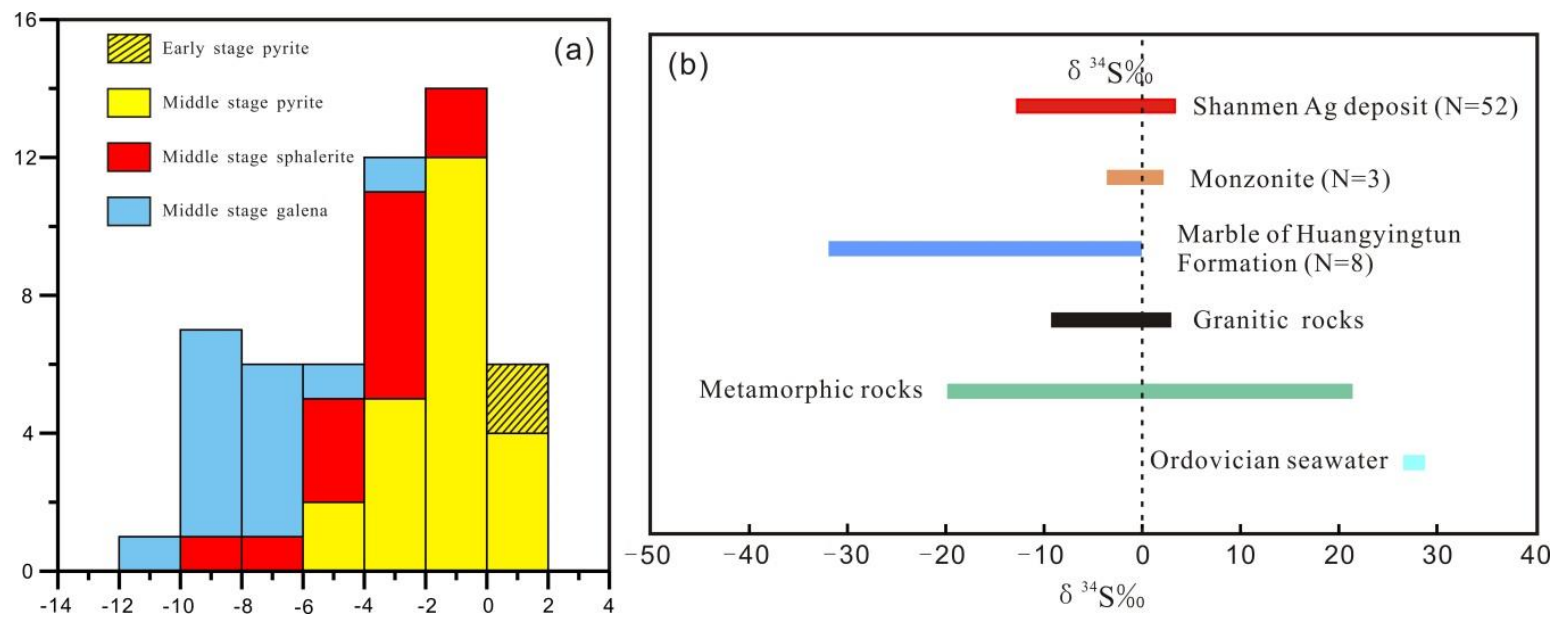

Figure 11. (a) Histogram of the $\delta^{34} \mathrm{~S}_{\mathrm{V}-\mathrm{CDT}}$ values of pyrite, sphalerite and galena from the Shanmen Ag deposit; (b) the $\mathrm{S}$ isotopic compositions of sulfides and host rocks (after White [32]).

The results of the $\mathrm{Pb}$ isotope study and some previous research results $[30,31]$ are shown in Table 5 and Figure 12. The isotopic ratios of pyrite in the early stage were ${ }^{206} \mathrm{~Pb} /{ }^{204} \mathrm{~Pb}=18.182-18.189$, ${ }^{207} \mathrm{~Pb} /{ }^{204} \mathrm{~Pb}=15.587-15.599$, and ${ }^{208} \mathrm{~Pb} /{ }^{204} \mathrm{~Pb}=38.207-38.251$, and those of pyrite, sphalerite, and galena in the middle stage were ${ }^{206} \mathrm{~Pb} /{ }^{204} \mathrm{~Pb}=18.091-18.149,{ }^{207} \mathrm{~Pb} /{ }^{204} \mathrm{~Pb}=15.473-15.548$, and ${ }^{208} \mathrm{~Pb} /{ }^{204} \mathrm{~Pb}=37.825-38.081$. The isotopic ratios of the host rock monzonite and quartz diorite are listed for contrast as well. These are ${ }^{206} \mathrm{~Pb} /{ }^{204} \mathrm{~Pb}=18.353-18.891,{ }^{207} \mathrm{~Pb} /{ }^{204} \mathrm{~Pb}=15.558-15.609$, and ${ }^{208} \mathrm{~Pb} /{ }^{204} \mathrm{~Pb}=38.242-38.850$.

Table 5. The Pb isotope compositions of sulfides from the Shanmen Ag deposit.

\begin{tabular}{|c|c|c|c|c|c|}
\hline $\begin{array}{l}\text { Sample } \\
\text { Number }\end{array}$ & Minerals & ${ }^{206} \mathrm{~Pb} /{ }^{204} \mathrm{~Pb}$ & ${ }^{207} \mathrm{~Pb} /{ }^{204} \mathrm{~Pb}$ & ${ }^{208} \mathrm{~Pb} /{ }^{204} \mathrm{~Pb}$ & References \\
\hline SM-21-1 & Pyrite & 18.182 & 15.587 & 38.207 & \multirow{4}{*}{ This study } \\
\hline SM-21-2 & Pyrite & 18.189 & 15.599 & 38.251 & \\
\hline SM-23-1 & Sphalerite & 18.148 & 15.548 & 38.081 & \\
\hline SM-23-2 & Galena & 18.143 & 15.543 & 38.062 & \\
\hline- & Pyrite & 18.104 & 15.473 & 37.877 & \multirow{3}{*}{ [33] } \\
\hline- & Galena & 18.091 & 15.478 & 37.852 & \\
\hline- & Sphalerite & 18.099 & 15.481 & 37.835 & \\
\hline- & Pyrite & 18.101 & 15.506 & 37.942 & \multirow{8}{*}{ [34] } \\
\hline- & Pyrite & 18.115 & 15.51 & 37.997 & \\
\hline- & Galena & 18.113 & 15.492 & 37.901 & \\
\hline- & Galena & 18.115 & 15.499 & 37.912 & \\
\hline- & Galena & 18.149 & 15.531 & 37.994 & \\
\hline- & Sphalerite & 18.093 & 15.479 & 37.825 & \\
\hline- & Sphalerite & 18.112 & 15.496 & 37.84 & \\
\hline- & Sphalerite & 18.115 & 15.488 & 37.86 & \\
\hline- & Monzonite & 18.56 & 15.583 & 38.712 & \multirow{3}{*}{ [34] } \\
\hline- & Monzonite & 18.891 & 15.609 & 38.85 & \\
\hline- & Quartz diorite & 18.353 & 15.558 & 38.242 & \\
\hline
\end{tabular}



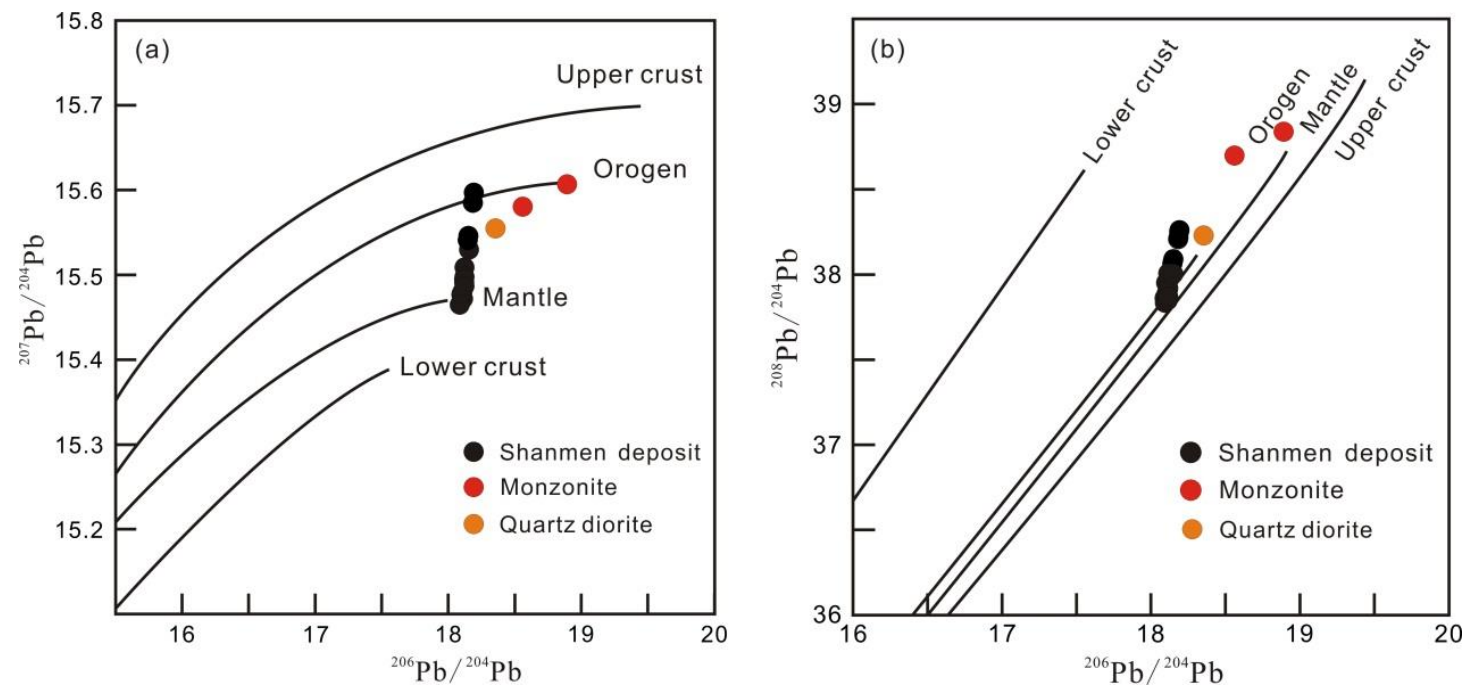

Figure 12. The $\mathrm{Pb}$ isotopic compositions of sulfides and ore-hosting rocks from the Shanmen Ag deposit. (a) ${ }^{207} \mathrm{~Pb} /{ }^{204} \mathrm{~Pb}$ versus ${ }^{206} \mathrm{~Pb} /{ }^{204} \mathrm{~Pb}$ and $(\mathbf{b}){ }^{208} \mathrm{~Pb} /{ }^{204} \mathrm{~Pb}$ versus ${ }^{206} \mathrm{~Pb} /{ }^{204} \mathrm{~Pb}$ (based map from Zartman and Doe [35]).

\section{Discussion}

\subsection{Nature and Evolution of the Ore-Forming Fluids}

The petrography and microthermometric results of fluid inclusions in this study indicate that the L-, V-, and C-type inclusions coexisted in early-stage (Stage I) at the Shanmen Ag deposit, with their homogenization temperature peaking at $340-280{ }^{\circ} \mathrm{C}$ and salinity peaking at $4-9 \mathrm{wt} \% \mathrm{NaCl}$ equivalent (Figure 8a,b). Various types of inclusions in the same quartz grain are normally distributed independently or in groups-indicating that they were captured at the same time and that the fluid was in an inhomogeneous state [36]. Furthermore, it indicates as well that the homogenization temperature can represent the temperature of the ore-forming fluid when the inclusions in this stage were captured [37]. The L-, V-, and C-type inclusions have similar temperatures but evidently different salinities (Figure 8). During the heating process, the L-type inclusions are homogenized to liquid phase, while the V-type inclusions are homogenized to the gas phase, resulting in an evident phase-separation characteristic. The phenomenon indicates that the fluid was boiling when these inclusions were captured [38]. Because of the relatively high temperature, only pyrite and a small amount of sphalerite and chalcopyrite are found in this stage. Minerals that normally form in medium-low temperature, such as silver, were not able to precipitate. Due to the existence of $\mathrm{CO}_{2}$ components in the bubbles (Figure $9 \mathrm{a}, \mathrm{b}$ ), the ore-forming fluid in the early stage belongs to the medium-high temperature, medium-low salinity $\mathrm{H}_{2} \mathrm{O}-\mathrm{NaCl}-\mathrm{CO}_{2}$ system.

The $\mathrm{CO}_{2}$ origin is the key to interpret the source of ore-forming fluid. According to the field phenomena and fluid inclusions components, almost all of the $\mathrm{CO}_{2}$-bearing quartz veins are distributed inside monzonite, whereas no quartz veins exist at the edge of marble. Therefore, $\mathrm{CO}_{2}$ is more likely to from magma rather than marble. The carbon isotopes of quartz show magmatic origin as well with a range of -4 to $-8 \%$ o (unpublished data) [39]. The solubility of $\mathrm{CO}_{2}$ increases with pressure and magma alkalinity [40], so that $\mathrm{CO}_{2}$-bearing fluids were released when magma migrated upward. Thus, we suggest that $\mathrm{CO}_{2}$ entered hydrothermal fluids as volatile components with a decrease of its solubility in magma. Although the content of $\mathrm{CO}_{2}$ is relatively low in the hydrothermal fluid system, its impact on mineralization cannot be ignored (discussed below).

Mainly V- and L-type inclusions-with rare C-type inclusions-exist in middle-stage (Stage II), which indicate a massive dissipation of $\mathrm{CO}_{2}$ components during fluid evolution. The possible reasons are; (1) that the physicochemical conditions changed rapidly due to mixing or boiling of fluids [31]; and 
(2) that the solubility of $\mathrm{CO}_{2}$ in the fluid is positively correlated with system pressure [41]. The sharp decreasing of pressure due to the fluid entering the fracture when ascending can lead to the escape of $\mathrm{CO}_{2}$ components as well. Because of the appearance of the two different phenomena (the V-type inclusion homogenized to vapor whereas the L-type homogenized to liquid) during heating and the greatly different salinity (Figure 13), the ore-forming fluids in the middle stage had the characteristics of mixing fluids with a different nature. By changing the $\mathrm{pH}$, temperature, pressure and other conditions of the fluid, fluid mixing was therefore the most important reason leading to $\mathrm{CO}_{2}$ escape and an important mechanism causing mineral precipitation as well. The homogenization temperature of inclusions in the middle stage peaked at $240-160{ }^{\circ} \mathrm{C}$, and the salinity peaked at $3-6 \mathrm{wt} \% \mathrm{NaCl}$ equivalent (Figure $8 \mathrm{c}, \mathrm{d}$ ). The components of the gas phase were mainly water with no $\mathrm{CO}_{2}$ components (Figure 9c,d), indicating that the ore-forming fluid belonged to a medium-low temperature and low-salinity $\mathrm{H}_{2} \mathrm{O}-\mathrm{NaCl}$ system.

Only L-type inclusions and a small number of PL-type inclusions were observed in late stage (Stage III). Their homogenization temperature peaked at $180-120{ }^{\circ} \mathrm{C}$ and their salinity peaked at $1-4 \mathrm{wt} \%$ $\mathrm{NaCl}$ equivalent (Figure 8e,f), which means that the ore-forming fluid belonged to a low-temperature and low-salinity $\mathrm{H}_{2} \mathrm{O}-\mathrm{NaCl}$ system.

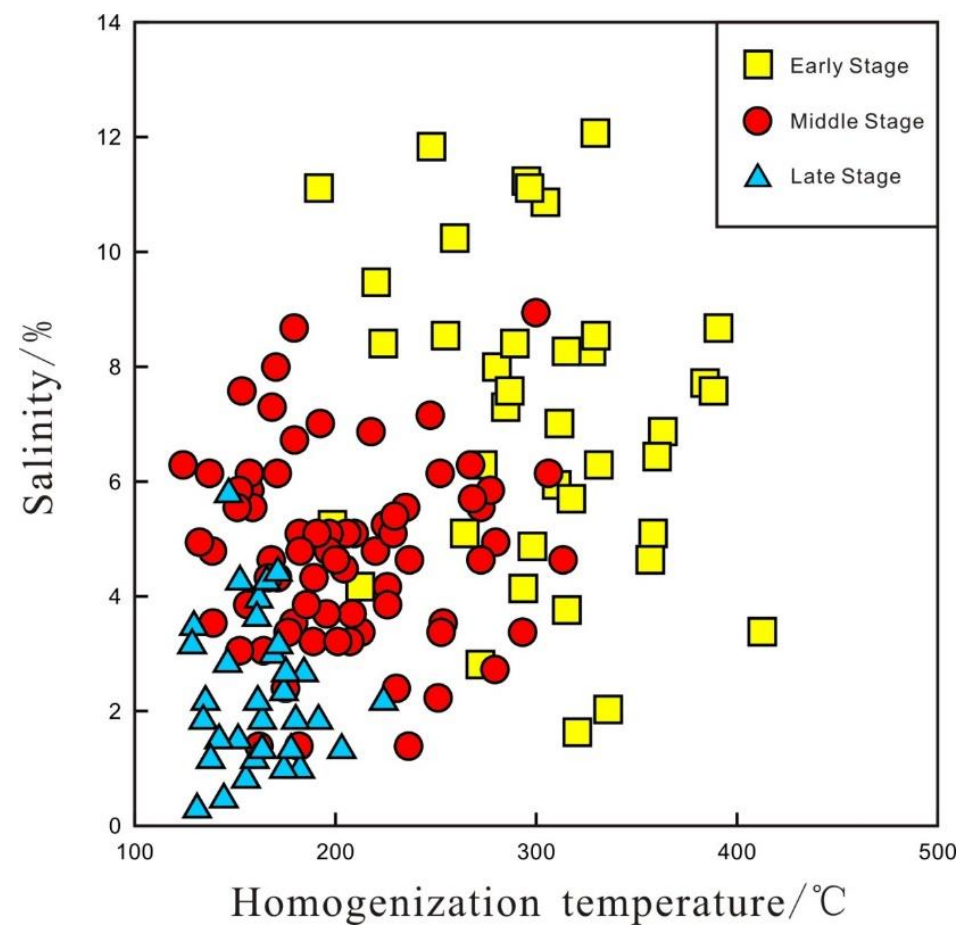

Figure 13. Homogenization temperature versus salinity of Shanmen Ag deposit.

\subsection{Sources of the Ore-Forming Fluid, Sulfur and Metals}

The compositions of the $\mathrm{H}-\mathrm{O}$ isotopes combined with the homogenization temperatures of the corresponding inclusions can effectively constrain the source of the ore-forming fluid and its evolutionary process [42]. In general, only early-stage minerals are able to reflect the characteristic of original ore-forming fluids [43]. The quartz veins in the early stage show relatively high $\delta^{18} \mathrm{O}_{\mathrm{H} 2 \mathrm{O}}$ values $(7.7 \%$ o to $8.1 \%$ o), consistent with those reported in other magmatic hydrothermal deposits [44]. In the diagram of $\delta^{18} \mathrm{O}_{\mathrm{H} 2 \mathrm{O}}-\delta \mathrm{D}$ (Figure 10), the values are plotted below the primary magmatic water area [25] and near the mantle juvenile fluid [26] and Au-Cu series magmatic water [27], indicating that the fluid was mainly derived from deep-source magma. The $\delta \mathrm{D}$ values are slightly lower than the distribution of the primary magmatic water ( -80 to $-40 \%$ ) [45]. This may be due to the influence of meteoric water components contained in the secondary inclusions [46] and/or meteoric water that have been input into the hydrothermal system since the early stage [47]. This phenomenon of low 
$\delta \mathrm{D}$ values is present in some other magmatic hydrothermal deposits as well, such as the Jiapigou gold deposit [48], Aerhada Pb-Zn-Ag deposit [49] and Haobugao Pb-Zn deposit [50], and they are all interpreted as being of magmatic origin. The plots in the diagram of $\delta^{18} \mathrm{O}_{\mathrm{H} 2 \mathrm{O}}-\delta \mathrm{D}$ (Figure 10) show an overall trend towards the meteoric water line from Stage I to III, meaning a relative shift towards isotopic depletion. The $\delta^{18} \mathrm{O}_{\mathrm{H} 2 \mathrm{O}}$ values of quartz in Stage III are extremely depleted-indicating the obvious involvement of meteoric water [47]. This is consistent with the low temperatures $\left(120-180{ }^{\circ} \mathrm{C}\right)$ and salinities (1-4 wt\%) of fluid inclusions in this stage as well. Except for the meteoric water, the relatively depleted isotopic values of fluids might be because of isotopic exchange by water-rock interaction or magma degassing [51,52]. Therefore, we conclude that the ore-forming fluid of the Shanmen Ag deposit was derived from magma, with continuous input of meteoric water during the evolution process.

The $S$ isotope composition of sulfides can reflect the source of mineralization in metal deposits. The $\delta^{34} \mathrm{~S}$ value of sulfide formed in hydrothermal fluid is affected by temperature, $\mathrm{pH}$, and oxygen and sulfur fugacity and is not always equal to the $\delta^{34} S$ value of the total hydrothermal sulfur $[53,54]$. Under low-oxygen fugacity conditions, sulfur is present in the forms of $\mathrm{HS}^{-}$and $\mathrm{S}^{2-}$, and the $\delta^{34} S$ value of sulfide is close to the total $\delta^{34} S$ value of the fluid $[55,56]$. The metal sulfide types of the Shanmen Ag deposit are mainly pyrite, chalcopyrite, sphalerite, and galena, with no sulfate minerals, and the values meet the order of distribution of $S$ isotope values under equilibrium conditions $\left(\delta^{34} S_{P y}\right.$ $\left.>\delta^{34} S_{S p}>\delta^{34} S_{G n}\right)$. Therefore, we believe that the $\delta^{34} S$ value of sulfide is approximately equal to the $\delta^{34} \mathrm{~S}$ value of sulfur from fluids $[29,57]$. The $\delta^{34} \mathrm{~S}$ values of the various sulfides range from -11.4 to $1.8 \%$, with a large distribution range and low $\delta^{34} \mathrm{~S}$ values. Existing data show that the relatively low $\delta^{34} \mathrm{~S}$ values (less than $-10 \%$ o) may be due to sulfur isotope fractionation in magma $\mathrm{SO}_{2}$ hydrolysis and fluid oxidation during the decrease of temperature or to the mixing of sulfur from sedimentation [58]. Because most of the $\delta^{34} S$ values coincide with the $\delta^{34} S$ values range of the monzonite and the marble in the Huangyingtun Formation-combined with the phenomenon that the marble is widely distributed in the mining area-we conclude that during the evolution of hydrothermal fluid, the sulfur in the sedimentary rocks was extracted into magma by assimilation. Therefore, it can be concluded that the sulfur of the Shanmen Ag deposit has a mixed source of magma and host rocks.

The composition of $\mathrm{Pb}$ isotopes of metal sulfides can effectively reflect the source of ore-forming metals [59-61]. In our study, the $\mathrm{Pb}$ isotope ratios of metal sulfides in the early- and middle-stages are in an apparently linear arrangement on the relationship diagram of average evolution curves of different geological units (Figure 12), indicating that they may have the same source or evolution process [62]. The projective positions are distributed between the upper crust and the mantle-mainly between the orogenic belt and the mantle-indicating that the $\mathrm{Pb}$ of the Shanmen Ag deposit is mainly the result of the mixing of $\mathrm{Pb}$ in the deep-mantle magma and high-radiogenic lead in the host rocks during the tectonic evolution of the orogenic belt [63]. The distribution of $\mathrm{Pb}$ isotope values of monzonite and quartz diorite in the mining area [34] is basically consistent with those of the ore minerals, implying the contribution of intrusive rocks. It is consistent with the field phenomenon that orebodies and intrusive rocks are closely associated as well. Furthermore, there is a small amount of $\mathrm{Pb}$ derived from a mixed source of crust and mantle, indicating that sedimentary rocks also contribute to the ore-forming materials.

\subsection{Genetic Type and Ore Genesis of the Shanmen Ag Deposit}

The ore-forming geological conditions and geological characteristics of the Shanmen Ag deposit, as well as fluid inclusions and $\mathrm{H}-\mathrm{O}$ isotope studies, indicate that the Shanmen Ag deposit is closely associated with the monzonite in the mining area. The orebodies showing ongoing features in veins and veinlets are obviously controlled by the faults and mostly grow inside intrusions (Figure 2). The transition from plastic to brittle conditions can be observed in intrusions (Figure 6a,b). The veins are quartz-rich in the core and sericite-muscovite-rich at the rims. The coarse-grained muscovite formed in the early stage of mineralization and sericite formed nearly simultaneously with silver mineralization. 
These characteristics might represent the existence of a continuum between magmatic and hydrothermal processes $[64,65]$. The ore-forming fluid in the early stage belonged to an $\mathrm{H}_{2} \mathrm{O}-\mathrm{NaCl}-\mathrm{CO}_{2}$ system at medium-high temperature and medium-low salinity and gradually evolved into a low-temperature and low-salinity $\mathrm{H}_{2} \mathrm{O}-\mathrm{NaCl}$ system during the mineralization process. These characteristics are similar to typical mesothermal hydrothermal deposits in Northeastern Asia such as the Haigou and Xiaobeigou gold deposits in the Southern Jilin Province and the Samwang Ag-Au deposit in Korea (Table 6). The H-O isotope compositions show that the ore-forming fluids were mainly derived from magma with input of meteoric water. The $\mathrm{S}$ and $\mathrm{Pb}$ isotope results of the metal sulfides indicate that the formation of the Shanmen Ag deposit was closely related to the granitic intrusions with minor contributions from local upper crustal components, which indicates that the ore-forming materials mainly came from magma. In summary, we consider the Shanmen Ag deposit to be a medium-low temperature magmatic hydrothermal vein-type deposit. 
Table 6. Comparison between the Shanmen Ag deposit and typical mesothermal and epithermal deposits in Northeastern Asia.

\begin{tabular}{|c|c|c|c|c|c|c|c|c|}
\hline Name & Host rocks & $\begin{array}{l}\text { Shapes of Ore } \\
\text { Bodies }\end{array}$ & Structures and Textures of Ores & $\begin{array}{l}\text { Metal Mineral } \\
\text { Assembles }\end{array}$ & $\begin{array}{r}\text { Wall Rock } \\
\text { Alterations }\end{array}$ & $\begin{array}{l}\text { Characteristics of Fluid } \\
\text { Inclusions }\end{array}$ & Genesis & References \\
\hline $\begin{array}{l}\text { Shanmen } \mathrm{Ag} \\
\text { deposit (Jilin } \\
\text { Province) }\end{array}$ & $\begin{array}{l}\text { Yanshanian } \\
\text { monzonite and } \\
\text { quartz diorite }\end{array}$ & $\begin{array}{l}\text { Layered, veined } \\
\text { and lenticular } \\
\text { shapes }\end{array}$ & $\begin{array}{l}\text { Veined, veinleted, disseminated, } \\
\text { banding structures and } \\
\text { euhedral-, subhedral- to } \\
\text { allotriomorphic-granular, } \\
\text { metasomatic and exsolution } \\
\text { textures }\end{array}$ & $\begin{array}{l}\text { Pyrite, galena, sphalerite, } \\
\text { chalcopyrite, native } \\
\text { silver, argentite, etc. }\end{array}$ & $\begin{array}{l}\text { Chloritization, } \\
\text { silicification, } \\
\text { sericitization, } \\
\text { carbonation, etc. }\end{array}$ & $\begin{array}{c}\text { Mainly two-phase } \\
\text { aqueous and multi-phase } \\
\mathrm{CO}_{2} \text {-bearing inclusions. } \\
\text { Fluid is mixed for } \\
\text { magmatic and meteoric } \\
\text { water }\end{array}$ & $\begin{array}{l}\text { Medium-low } \\
\text { temperature } \\
\text { magmatic } \\
\text { hydrothermal } \\
\text { deposit }\end{array}$ & $\begin{array}{l}\text { This } \\
\text { paper }\end{array}$ \\
\hline $\begin{array}{l}\text { Niujuan Ag } \\
\text { deposit (Hebei } \\
\text { Province) }\end{array}$ & $\begin{array}{l}\text { Hercynian and } \\
\text { Yanshanian } \\
\text { granite }\end{array}$ & Veined shape & $\begin{array}{l}\text { Brecciated, disseminated, } \\
\text { cellular, massed structures and } \\
\text { metasomatic, poikilitic, } \\
\text { euhedral-, to } \\
\text { allotriomorphic-granular } \\
\text { textures }\end{array}$ & $\begin{array}{c}\text { Marcasite, galena, pyrite, } \\
\text { chalcopyrite, sphalerite, } \\
\text { native silver, argentite, } \\
\text { etc. }\end{array}$ & $\begin{array}{l}\text { Silicification, } \\
\text { potassic alteration, } \\
\text { sericitization, } \\
\text { chloritization, } \\
\text { kaolinization, } \\
\text { carbonation, etc. }\end{array}$ & $\begin{array}{l}\text { Mainly two-phase } \\
\text { aqueous fluid inclusions. } \\
\text { Fluid is mixed for } \\
\text { magmatic and meteoric } \\
\text { water }\end{array}$ & $\begin{array}{l}\text { Epithermal } \\
\text { deposit }\end{array}$ & [66] \\
\hline $\begin{array}{l}\text { Haigou Au } \\
\text { deposit (Jilin } \\
\text { Province) }\end{array}$ & Monzonite & $\begin{array}{l}\text { Mainly veined } \\
\text { shape }\end{array}$ & $\begin{array}{c}\text { Disseminated, massed } \\
\text { structures and euhedral-, } \\
\text { subhedral- to } \\
\text { allotriomorphic-granular, } \\
\text { metasomatic textures }\end{array}$ & $\begin{array}{l}\text { Pyrite, galena, sphalerite, } \\
\text { chalcopyrite, native gold, } \\
\text { calaverite, etc. }\end{array}$ & $\begin{array}{l}\text { Silicification, } \\
\text { potassic alteration, } \\
\text { sericitization, } \\
\text { chloritization, } \\
\text { carbonation, etc. }\end{array}$ & $\begin{array}{l}\text { Mainly two-phase } \\
\text { aqueous and multi-phase } \\
\mathrm{CO}_{2} \text {-bearing inclusions. } \\
\text { Fluid is mainly derived } \\
\text { from magmatic water }\end{array}$ & $\begin{array}{c}\text { Mesothermal } \\
\text { deposit }\end{array}$ & [67] \\
\hline $\begin{array}{l}\text { Xiaobeigou Au } \\
\text { deposit (Jilin } \\
\text { Province) }\end{array}$ & Quartz diorite & $\begin{array}{l}\text { Veined and } \\
\text { reticular veined } \\
\text { shapes }\end{array}$ & $\begin{array}{c}\text { Veined, reticular veined, } \\
\text { disseminated structures and } \\
\text { allotriomorphic-granular, } \\
\text { fragmented, metasomatic } \\
\text { textures }\end{array}$ & $\begin{array}{l}\text { Pyrite, chalcopyrite, } \\
\text { galena, sphalerite, native } \\
\text { gold, etc. }\end{array}$ & $\begin{array}{l}\text { Silicification, } \\
\text { sericitization, } \\
\text { potassic alteration, } \\
\text { chloritization, } \\
\text { carbonation, etc. }\end{array}$ & $\begin{array}{l}\text { Mainly two-phase } \\
\text { aqueous and multi-phase } \\
\mathrm{CO}_{2} \text {-bearing inclusions. } \\
\text { Fluid is mainly derived } \\
\text { from magmatic water }\end{array}$ & $\begin{array}{c}\text { Mesothermal } \\
\text { deposit }\end{array}$ & [68] \\
\hline $\begin{array}{l}\text { Samwang Ag-Au } \\
\text { deposit (Korea) }\end{array}$ & Jurassic granite & $\begin{array}{c}\text { Veined and } \\
\text { lenticular shapes }\end{array}$ & $\begin{array}{l}\text { Veined, disseminated, massed } \\
\text { structures and euhedral-, } \\
\text { subhedral- to } \\
\text { allotriomorphic-granular, } \\
\text { metasomatic, fragmented } \\
\text { textures }\end{array}$ & $\begin{array}{c}\text { Pyrite, arsenopyrite, } \\
\text { galena, sphalerite, } \\
\text { chalcopyrite and other } \\
\text { Au-Ag-bearing minerals }\end{array}$ & $\begin{array}{l}\text { Silicification, } \\
\text { potassic alteration, } \\
\text { sericitization, } \\
\text { chloritization, etc. }\end{array}$ & $\begin{array}{l}\text { Mainly two-phase } \\
\text { aqueous and multi-phase } \\
\mathrm{CO}_{2} \text {-bearing inclusions. } \\
\text { Fluid is mainly derived } \\
\text { from magmatic water }\end{array}$ & $\begin{array}{l}\text { Mesothermal } \\
\text { deposit }\end{array}$ & [69] \\
\hline
\end{tabular}


The monzonite exposed in the ore district can be identified as the ore-forming intrusion based on the geological evidence as follows. Firstly, the ore bodies mostly occur in fractures and approximately parallel to monzonite, but those in quartz diorite have an apparent boundary with wall rocks. This indicates that the mineralization has a very close relationship with monzonite rather than quartz diorite. Secondly, the $\mathrm{H}$ and $\mathrm{O}$ isotope data show that the early ore-forming fluids were mainly of magmatic origin. Monzonite, therefore, might be the source of magma fluids. Finally, silicification and sericitization related to the mineralization is found in monzonite as well and becomes weaker as the distance from the orebodies increases, but the quartz diorite is mainly affected by chloritization. Zircon U-Pb dating of monzonite determined by LA-MC-ICP-MS gave an age of $164 \mathrm{Ma}$ (unpublished data). Therefore, we consider that the ore-forming age of the Shanmen Ag deposit should be consistent with this age, in the middle-late Jurassic. In this period, a series of medium-temperature hydrothermal gold deposits related to intrusions formed in the eastern segment of the northern margin of the North China Plate, such as some gold deposits in the Jiapigou-Haigou Metallogenic Belt in Southeastern Jilin Province $[66,67]$. The ore-forming background studies show that the collisions of micro-continental blocks in NE China had finished. Subsequently, this area evolved into the stage of the Pacific Rim Structural Domain. The Paleo-Pacific Plate began to subduct westward, and NE China was in the active continental margin and island arc environment formed by plate subduction $[9,70]$. The original magma was mostly formed by the partial melting of upper mantle materials and/or crust-mantle mixing, which is consistent as well with the result that the mineralization materials of the Shanmen Ag deposit had a mixed source of mantle and crust. Wilkinson et al. [71] concluded that giant ore deposits can form rapidly from small volumes of magmatic-origin metal-rich fluid in subduction settings. There is some silver mineralization occurring in subduction settings in the world, such as in the Imiter deposit in Morocco and the Rochester deposit in the US [65,72]. They both have similar characteristics to the Shanmen Ag deposit such as medium-low ore-forming temperature, vein-type mineralization and control by structures. Besides, comprehensive studies indicate that the Shanmen Ag deposit and the gold deposits in the Jiapigou-Haigou Metallogenic Belt have great similarities in terms of their geological characteristics, physicochemical conditions, and ore-forming tectonic setting [66,73]. Therefore, we consider that the Ag mineralization and related magmatism of the Shanmen Ag deposit were in the tectonic background of an active continental margin and island arc due to the Paleo-Pacific Plate obliquely subducting to Eastern Eurasia in Yanshanian (Figure 14).

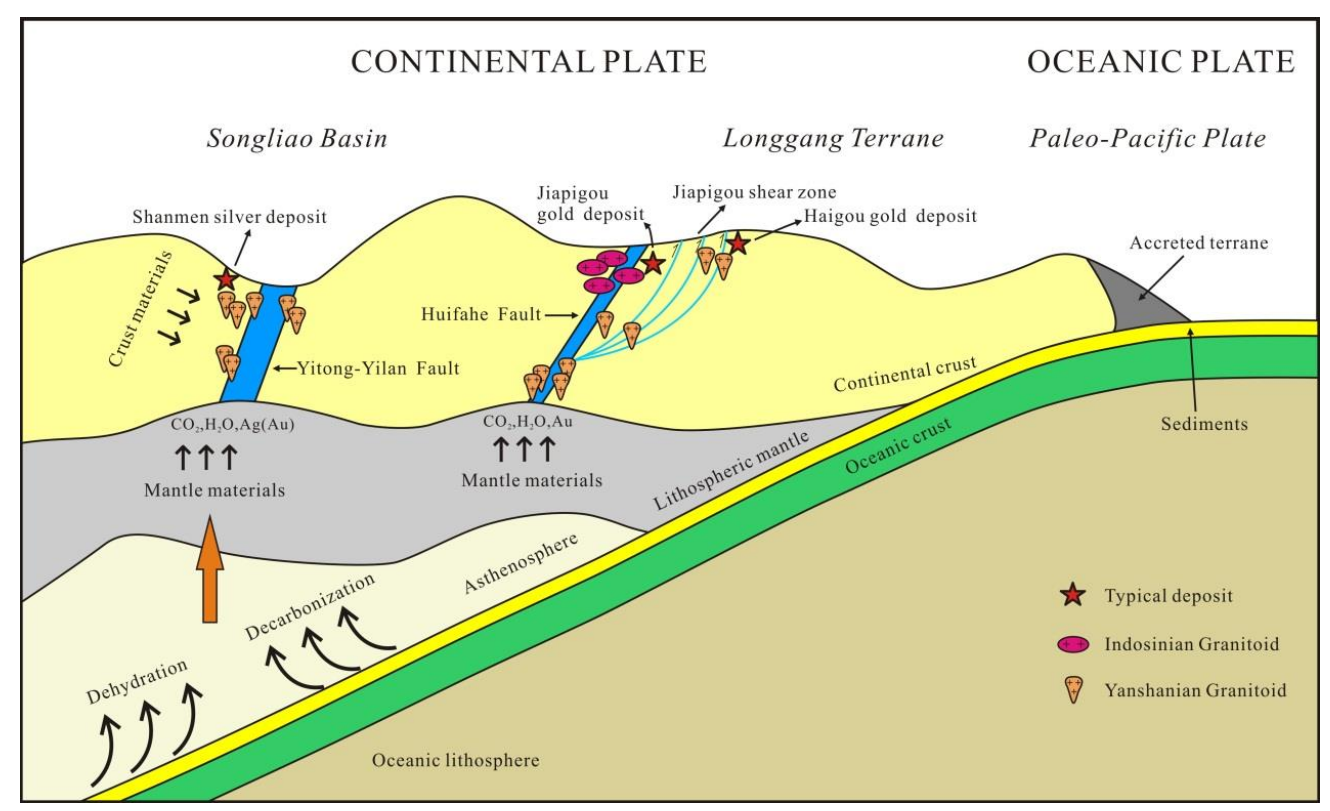

Figure 14. Schematic model showing the tectonic setting and ore-forming process of the Shanmen Ag deposit and gold deposits in the Jiapigou-Haigou Metallogenic Belt (after Groves and Santosh [74] and Li et al. [68]). 
The mineralization process of the Shanmen Ag deposit can be summarized as follows. Under the influence of the Paleo-Pacific Plate subducting beneath the Eurasian continent in the Yanshanian period, intense magmatism and deformation occurred extensively in the Southern Jilin Province. The NNE trend faults in this area are considered to be the result of the westward subduction. Partial melting of the lower crust and ascension of the asthenosphere caused by the interaction between oceanic crust and lithospheric mantle led to the upwelling of magma along deep fractures $[8,48,70]$. The $\mathrm{CO}_{2}$ metal-rich magma reacted with surrounding rocks and gradually condensated during ascension-resulting in the input of more crust materials. With the magma crystallized in continental crust, hydrothermal fluid was exsolved. Silver and base metals such as lead and zinc are mainly transported in the form of chlorine complexes under acidic conditions with high temperature, salinity and oxygen fugacity $[75,76]$. As the fluid evolves, temperature, salinity and oxygen fugacity decrease while $\mathrm{pH}$ rises, causing the stability of the chlorine complex to be destroyed and the main complex form transferred to a sulfur-hydrogen complex [75,77]. Therefore, in the high-temperature magmatic fluid system of the Shanmen Ag deposit, the Ag element was most likely transported in the form of chlorine complexes [78]. As the hydrothermal fluid migrated to the shallow part of the earth's crust along faults, the fluid system boiled due to the sudden release of pressure in the tectonic fracture and cooled because of the removal of high-temperature vapour $[75,79]$. The metal-containing sulfur-hydrogen complex began to precipitate pyrite and other sulfides in the early stage, with the fluid inclusions exhibiting two extremes of low-salinity carbon-rich inclusions and medium-salinity gas-liquid inclusions. With the input of cold meteoric water, fluid mixing occurred, and its temperature and salinity further decreased, causing the ore-forming fluid to reach the immiscible zone of the $\mathrm{CO}_{2}$ and $\mathrm{H}_{2} \mathrm{O}$ phase [80]. This led to the loss of a large amount of volatiles such as $\mathrm{CO}_{2}$, decrease of fluid oxygen fugacity, and increase of reductivity. These changes of physical and chemical conditions of fluids reduced the stability of numerous metal complexes, causing the precipitation of low-temperature crystalline minerals such as lead, zinc, silver and the formation of a large amount of metal sulfides. Afterward, the liquids contained almost no metal elements and the mineralization evolved into the late stage, forming low-temperature hydrothermal alteration such as carbonation.

The $\mathrm{CO}_{2}$ component has an important influence on the oxygen fugacity and $\mathrm{pH}$ of hydrothermal fluids [81]. During the mineralization process from early-stage with deficient sulfides to middle-stage with polymetallic sulfides, the nature of the fluid changed from a medium-high temperature, medium-low salinity $\mathrm{H}_{2} \mathrm{O}-\mathrm{NaCl}-\mathrm{CO}_{2}$ system to a medium-low temperature, low-salinity $\mathrm{H}_{2} \mathrm{O}-\mathrm{NaCl}$ system, indicating that the decrease of temperature and the $\mathrm{CO}_{2}$ component had an important role in promoting the precipitation of metals such as lead, zinc, and silver. Therefore, we believe that the fluid mixing of fluids of different nature in the middle stage was the main mechanism of mineral precipitation-which was carried out in a reducing environment-and that the release of $\mathrm{CO}_{2}$ and the relatively low temperature were an important cause of the precipitation and enrichment of the silver minerals.

\section{Conclusions}

(1) The Shanmen Ag deposit is hosted in monzonite and quartz diorite and has developed some typical hydrothermal alterations such as silicification, sericitization and chloritization near ores. The mineralization process can be divided into Stage I (pyrite-quartz stage), Stage II (quartz-Ag-polymetallic-sulfide stage), and Stage III (carbonate-quartz stage).

(2) The fluid inclusions in ore-bearing quartz in the Shanmen Ag deposit mainly include liquid-rich, vapor-rich, and $\mathrm{CO}_{2}$-bearing multiphase inclusions. The ore-forming fluid changed from a medium-high temperature, medium-low salinity $\mathrm{H}_{2} \mathrm{O}-\mathrm{NaCl}-\mathrm{CO}_{2}$ system to a low-temperature, low-salinity $\mathrm{H}_{2} \mathrm{O}-\mathrm{NaCl}$ system during fluid evolution.

(3) The genetic type of the Shanmen Ag deposit belongs to the intrusion-related medium-low temperature hydrothermal vein-type. The $\mathrm{H}$-O isotope data suggests that ore-forming fluids were derived mainly from magmatic water with the input of meteoric water. The $\mathrm{S}$ isotope data shows that 
the sulfur in ore-forming fluid has mixed source of magma and host rocks. Pb isotope data indicates that metals are of mixed sources from the mantle and crust.

(4) The existence of brittle fractures led to a sudden decrease in the lithostatic pressure, causing boiling of the ore-forming fluid. In Stage II, the mixing of hot magmatic water and cold meteoric water caused the temperature and salinity to decrease, the $\mathrm{CO}_{2}$ component to escape, the fluid reducibility to increase, and a large amount of sulfides to precipitate. The release of $\mathrm{CO}_{2}$ and low temperature are the most important factors that trigger the precipitation of silver and other minerals, and fluid mixing is the main mineralization mechanism.

Author Contributions: Conceptualization, X.S. and Y.R.; formal analysis, X.S.; investigation, X.S., P.C., Y.H. and Y.G.; methodology, X.S. and P.C.; supervision, Y.R.; writing—original draft, X.S.

Funding: This work is financially supported by the National Key R and D Program of China (Number 2017YFC0601304).

Acknowledgments: We want to thank the geological workers from the Siping Horoc Silver Industry Company for their help during the field geological work. We are also deeply grateful to anonymous reviewers for their reviews and constructive suggestions, and to Panagiotis Voudouris for his editorial handling.

Conflicts of Interest: The authors declare no conflict of interest.

\section{References}

1. Safonova, I.Y.; Santosh, M. Accretionary complexes in the Asia-Pacific region: Tracing archives of ocean plate stratigraphy and tracking mantle plumes. Gondwana Res. 2014, 25, 126-158. [CrossRef]

2. Wu, F.Y.; Sun, D.Y.; Ge, W.C.; Zhang, Y.B.; Grant, M.L.; Wilde, S.A.; Jahn, B.M. Geochronology of the Phanerozoic granitoids in northeastern China. J. Asian Earth Sci. 2011, 41, 1-30. [CrossRef]

3. Wang, F.K. Analysis on metallogenetic conditions of the Shanmen silver deposit in Siping, Jilin Province. Jilin Geol. 1994, 13, 9-16. (In Chinese)

4. Huang, W.B.; Shen, H.C.; Fen, L. Isotopic geochemistry of Mesozoic igneous rocks and mineralization of Shanmen silver deposit in Yi-Su Basin, Jilin Province. In Mineral Deposit Research: Meeting the Global Challenge; Mao, J., Bierlein, F.P., Eds.; Springer: Berlin/Heidelberg, Germany, 2005.

5. Tian, W.S.; Shao, J.B. Geological characteristics of the Shanmen silver deposit in Siping, Jilin Province. Jilin Geol. 1991, 10, 152-160. (In Chinese)

6. Fu, S.D. Metallogenic characteristics in the Shanmen silver deposit, Siping. Jilin Geol. 1992, 1, 10-19. (In Chinese)

7. Wang, Z.G. Study on Metallogenesis of Mesozoic Endogenetic Metal Deposits in the Eastern Part of Jilin Province. Ph.D. Thesis, Jilin University, Changchun, China, 2012. (In Chinese).

8. Yang, H.; Ge, W.C.; Zhao, G.C.; Yu, J.J.; Zhang, Y.L. Early Permian-Late Triassic granitic magmatism in the Jiamusi-Khanka Massif, eastern segment of the Central Asian Orogenic Belt and its implications. Gondwana Res. 2015, 27, 1509-1533. [CrossRef]

9. Xu, W.L.; Wang, F.; Pei, F.P.; Meng, E.; Tang, J.; Xu, M.J.; Wang, W. Mesozoic tectonic regimes and regional ore-forming background in NE China: Constraints from spatial and temporal variations of Mesozoic volcanic rock associations. Acta Petrol. Sin. 2013, 29, 339-353. (In Chinese)

10. Wang, B.; Zhou, J.B.; Wilde, S.A.; Zhang, X.Z.; Ren, S.M. The timing of final closure along the Changchun-Yanji suture zone: Constraints from detrital zircon $\mathrm{U}-\mathrm{Pb}$ dating of the Triassic Dajianggang Formation, NE China. Lithos 2016, 261, 216-231. [CrossRef]

11. Wang, F.; Xu, Y.G.; Xu, W.L.; Yang, L.; Wu, W.; Sun, C.Y. Early Jurassic calc-alkaline magmatism in northeast China: Magmatic response to subduction of the paleo-pacific plate beneath the Eurasian Continent. J. Asian Earth Sci. 2017, 143, 249-268. [CrossRef]

12. Ma, X.H.; Zhu, W.P.; Zhou, Z.H.; Qiao, S.L. Transformation from Paleo-Asian Ocean closure to Paleo-Pacific subduction: New constraints from granitoids in the eastern Jilin-Heilongjiang Belt, NE China. J. Asian Earth Sci. 2017, 144, 261-286. [CrossRef]

13. Pei, F.P.; Zhang, Y.; Wang, Z.W.; Cao, H.H.; Xu, W.L.; Wang, Z.J.; Wang, F.; Yang, C. Early-Middle Paleozoic subduction-collision history of the south-eastern Central Asian Orogenic Belt: Evidence from igneous and metasedimentary rocks of central Jilin Province, NE China. Lithos 2016, 261, 164-180. [CrossRef] 
14. Gu, C.C.; Zhu, G.; Li, Y.J.; Su, N.; Xiao, S.Y.; Zhang, S.; Liu, C. Timing of deformation and location of the eastern Liaoyuan Terrane, NE China: Constraints on the final closure time of the Paleo-Asian Ocean. Gondowana Res. 2018, 60, 194-212. [CrossRef]

15. Zhang, H.H.; Wang, F.; Xu, W.L.; Cao, H.H.; Pei, F.P. Petrogenesis of Early-Middle Jurassic intrusive rocks in northern Liaoning and central Jilin provinces, northeast China: Implications for the extent of spatial-temporal overprinting of the Mongol-Okhotsk and Paleo-Pacific tectonic regimes. Lithos 2016, 132-147, $256-257$. [CrossRef]

16. Feng, M.; Chen, L.; Zhou, P.F.; Cui, L.X. Geologic characteristics and prospecting indicators of the Shanmen Silver deposit in Siping, Jilin Province. Geol. Res. 2010, 19, 215-220. (In Chinese)

17. Ren, Y.S.; Niu, J.P.; Lei, E.; Wang, H.; Wang, X. Geological and geochemical characteristics and metallogenesis of Sanjiazi scheelite deposit in Siping area, Jilin Province. J. Jilin Univ. 2010, 40, 314-320. (In Chinese)

18. Li, T.; Ni, S.B. Abundance of Chemical Elements in the Earth and the Earth's Crust, 1st ed.; Geological Publishing House: Beijing, China, 1990; pp. 29-90.

19. Potter, R.W.; Clynne, M.A.; Brown, D.L. Freezing point depression of aqueous sodium chloride solutions. Econ. Geol. 1978, 73, 284-285. [CrossRef]

20. Liu, B.; Duan, G.X. The density and isochoric formulae for $\mathrm{NaCl}-\mathrm{H}_{2} \mathrm{O}$ fluid inclusions (salinity $\leq 25 \mathrm{wt}$. \%) and their applications. Acta Miner. Sin. 1987, 7, 345-352. (In Chinese)

21. Bozzo, A.T.; Chen, H.S.; Kass, J.R.; Barduhn, A.J. The properties of the hydrates of chlorine and carbon dioxide. Desalination 1975, 16, 303-320. [CrossRef]

22. Touret, J.; Bottinga, Y. Equation of state of $\mathrm{CO}_{2}$; application to carbonic inclusions. Bull. Miner. 1979, 102, 577-583. [CrossRef]

23. Clayton, R.N.; O’Neil, J.R.; Mayeda, T.K. Oxygen isotope exchange between quartz and water. J. Geophys. Res. 1972, 77, 3057-3067. [CrossRef]

24. Roedder, E. Fluid inclusions. Rev. Miner. 1984, 12, 1-644.

25. Taylor, H.P. The application of oxygen and hydrogen isotope studies to problems of hydrothermal alteration and ore deposition. Econ. Geol. 1974, 69, 843-883. [CrossRef]

26. Craig, H.; Lupton, J.E. Lupton primordial neon, helium and hydrogen in oceanic basalts. Earth Planet. Sci. Lett. 1976, 31, 369-385. [CrossRef]

27. Zhang, L.G. Hydrogen, oxygen, sulfur and carbon isotope geochemistry of the Lianhuashan porphyry type tungsten deposit. Miner. Depos. 1985, 4, 54-63. (In Chinese)

28. Huang, W.B.; Shen, H.C. Isotopic Geochemistry evidence for genesis of Shanmen silver deposit, Siping. Geol. Pros. 2006, 42, 46-50. (In Chinese)

29. Ohmoto, H.; Rye, R.O. Isotopes of sulfur and carbon. In Geochemistry of Hydrothermal Ore Deposits, 2nd ed.; Barnes, H.L., Ed.; John Wiley \& Sons, Inc.: New York, NY, USA, 1979; pp. 509-567.

30. Ohmoto, H. Systematics of sulfur and carbon isotopes in hydrothermal ore deposits. Econ. Geol. 1972, 67, 551-578. [CrossRef]

31. Zhang, Y.C.; Gao, S.B.; Zheng, Y.Y.; Jiang, J.S.; Zhang, S.Z.; Jiang, X.J.; Guo, X.R. Mineralogy, fluid inclusions and $\mathrm{C}-\mathrm{H}-\mathrm{O}-\mathrm{S}-\mathrm{Pb}$ isotopes of the Palaeocene Longgen $\mathrm{Pb}-\mathrm{Zn}$ deposit in the western Nyainqentanglha belt, Tibet. Ore Geol. Rev. 2018, 102, 18-43. [CrossRef]

32. White, W.M. Geochemistry, 9th ed.; Publication, John Wiley and Sons Ltd.: New York, NY, USA, 2013; pp. 406-409.

33. Jiang, F.P.; Deng, L.S.; Liu, D.W.; Wang, H.Y. The characteristics of stable isotopes and gas-liquid inclusions of the Shanmen Ag deposit, Jilin Province. Jilin Geol. 2007, 26, 47-50. (In Chinese)

34. Zang, Y.S.; Wang, F.K. The geological characteristics of sulfur isotopes in the Shanmen silver deposit, Siping. Jilin Geol. 1992, 1, 22-29. (In Chinese)

35. Zartman, R.E.; Doe, B.R. Plumbotectonics-the model. Tectonophysics 1981, 75, 135-162. [CrossRef]

36. Xiong, S.F.; He, M.C.; Yao, S.Z.; Cui, Y.B.; Shi, G.Z.; Ding, Z.J.; Hu, X.L. Fluid evolution of the Chalukou giant Mo deposit in the northern Great Xing'an Range, NE China. Geol. J. 2015, 50, 720-738. [CrossRef]

37. Gao, S.; Xu, H.; Quan, S.L.; Zang, Y.Q.; Wang, T. Geology, hydrothermal fluids, H-O-S-Pb isotopes, and Rb-Sr geochronology of the Daxintun orogenic gold deposit in Heilongjiang province, NE China. Ore Geol. Rev. 2018, 92, 569-587. [CrossRef] 
38. Zhang, Y.; Xing, S.W.; Song, Q.H.; Yu, Z.T.; Liang, S.F. Fluid and metal sources of the Changfagou porphyry copper deposit, southern Jilin Province, NE China: Constraints from fluid inclusions and $\mathrm{H}-\mathrm{O}-\mathrm{S}-\mathrm{Pb}$ isotope systematics. Geol. J. 2017, 53, 2746-2758. [CrossRef]

39. Luque, F.J.; Crespo-Feo, E.; Barrenechea, J.F.; Ortega, L. Carbon isotopes of graphite: Implications on fluid history. Geosci. Front. 2012, 3, 197-207. [CrossRef]

40. Lowenstern, J.B. Carbon dioxide in magmas and implications for hydrothermal systems. Miner. Depos. 2001, 36, 490-502. [CrossRef]

41. Ruan, B.X.; Lv, X.B.; Yang, W.; Liu, S.T.; Yu, Y.M.; Wu, C.M. Geology, geochemistry and fluid inclusions of the Bianjiadayuan $\mathrm{Pb}-\mathrm{Zn}-\mathrm{Ag}$ deposit, Inner Mongolia, NE China: Implications for tectonic setting and metallogeny. Ore Geol. Rev. 2015, 71, 121-137. [CrossRef]

42. Pirajno, F. Hydrothermal Processes and Mineral Systems; Springer: Berlin, Germany, 2009; p. 1250.

43. Chai, P.; Sun, J.G.; Hou, Z.Q.; Xing, S.W.; Wang, Z.Y. Geological, fluid inclusion, H-O-S-Pb isotope, and Ar-Ar geochronology constraints on the genesis of the Nancha gold deposit, southern Jilin Province, northeast China. Ore Geol. Rev. 2016, 72, 1053-1071. [CrossRef]

44. Cooke, D.R.; Deyell, C.L.; Waters, P.J.; Gonzales, R.I.; Zaw, K. Giant porphyry deposits: Characteristics, distribution, and tectonic controls. Econ. Geol. 2011, 100, 801-818. [CrossRef]

45. Rollinson, H.R. Using Geochemical Data: Evaluation, Presentation, Interpretation; Longman Scientific and Technical Press: Harlow, UK, 1993; p. 352.

46. Goldfarb, R.J.; Groves, D.I. Orogenic gold: Common or evolving fluid and metal sources through time. Lithos 2015, 233, 2-26. [CrossRef]

47. Zhang, F.F.; Wang, Y.H.; Liu, J.J.; Wang, C.J. Ore genesis and hydrothermal evolution of the Wulandele Mo deposit, Inner Mongolia, Northeast China: Evidence from geology, fluid inclusions and $\mathrm{H}-\mathrm{O}-\mathrm{S}-\mathrm{Pb}$ isotopes. Ore Geol. Rev. 2018, 93, 181-199. [CrossRef]

48. Zeng, Q.D.; Wang, Z.C.; He, H.Y. Multiple isotope composition (S, Pb, H, O, He, and Ar) and genetic implications for gold deposits in the Jiapigou gold belt, Northeast China. Miner. Depos. 2014, 49, 145-164. [CrossRef]

49. Ke, L.L.; Zhang, H.Y.; Liu, J.J.; Zhai, D.G.; Guo, D.H.; Yang, J.K.; Tan, Q.; Xu, Y.W.; Zhang, M.; Wang, S.G. Fluid Inclusion, $\mathrm{H}-\mathrm{O}, \mathrm{S}, \mathrm{Pb}$ and noble gas isotope studies of the Aerhada $\mathrm{Pb}-\mathrm{Zn}-\mathrm{Ag}$ deposit, Inner Mongolia, NE China. Ore Geol. Rev. 2017, 88, 304-316. [CrossRef]

50. Wang, C.Y.; Li, J.F.; Wang, K.Y. Fluid Inclusions, stable isotopes, and geochronology of the Haobugao lead-zinc deposit, Inner Mongolia, China. Resour. Geol. 2018, 69, 1-20. [CrossRef]

51. Rye, R.O. The evolution of magmatic fluids in the epithermal environment: The stable isotope perspective. Econ. Geol. 1993, 88, 733-752. [CrossRef]

52. Harris, A.C.; Golding, S.D. New evidence of magmatic-fluid-related phyllic alteration: Implications for the genesis of porphyry $\mathrm{Cu}$ deposits. Geology 2002, 30, 335-338. [CrossRef]

53. Rye, R.O.; Ohmoto, H. Sulfur and carbon isotopes and ore genesis: A review. Econ. Geol. 1974, 69, 826-842. [CrossRef]

54. Ohmoto, H. Stable isotope geochemistry of ore deposits. Rev. Miner. Geochem. 1986, 16, 491-559.

55. Ohmoto, H.; Goldhaber, M. Sulfur and carbon isotopes. In Geochemistry of Hydrothermal Ore Deposits, 3rd ed.; Barnes, H.L., Ed.; John Wiley \& Sons, Inc.: New York, NY, USA, 1997; pp. 517-611.

56. Guo, W.K.; Zeng, Q.D.; Guo, Y.P.; Wang, Y.B.; Zhang, B. Rb-Sr dating of sphalerite and S-Pb isotopic studies of the Xinxing cryptoexplosive breccia $\mathrm{Pb}-\mathrm{Zn}-(\mathrm{Ag})$ deposit in the southeastern segment of the Lesser Xing'an-Zhangguangcai metallogenic belt, NE China. Ore Geol. Rev. 2018, 99, 75-85. [CrossRef]

57. Li, T.G.; Wu, G.; Liu, J.; Wang, G.R.; Hu, Y.Q.; Zhang, Y.F.; Luo, D.F.; Mao, Z.H.; Xu, B. Geochronology, fluid inclusions and isotopic characteristics of the Chaganbulagen $\mathrm{Pb}-\mathrm{Zn}-\mathrm{Ag}$ deposit, Inner Mongolia, China. Lithos 2016, 261, 340-355. [CrossRef]

58. Gao, R.Z.; Xue, C.J.; Lv, X.B.; Zhao, X.B.; Yang, Y.S.; Li, C.C. Genesis of the Zhengguang gold deposit in the Duobaoshan ore field, Heilongjiang Province, NE China: Constraints from geology, geochronology and S-Pb isotopic compositions. Ore Geol. Rev. 2017, 84, 202-217. [CrossRef]

59. Bierlein, F.P.; McNaughton, N.J. Pb isotope fingerprinting of mesothermal gold deposits from central Victoria, Australia: Implications for ore genesis. Miner. Depos. 1998, 33, 633-638. [CrossRef] 
60. Zhou, Z.J.; Chen, Y.J.; Jiang, S.Y.; Zhao, H.X.; Qin, Y.; Hu, C.J. Geology, geochemistry and ore genesis of the Wenyu gold deposit, Xiaoqinling gold field, Qinling Orogen, southern margin of North China Craton. Ore Geol. Rev. 2014, 59, 1-20. [CrossRef]

61. Ma, Y.; Jiang, S.Y.; Li, H.L. Isotope geochemistry and genesis of the Liyuan gold deposit, Shanxi, North China. Ore Geol. Rev. 2018, 92, 129-143. [CrossRef]

62. Harris, A.C.; Golding, S.D.; White, N.C. Bajo de la Alumbrera copper-gold deposit: Stable isotope evidence for a porphyry-related hydrothermal system dominated by magmatic aqueous fluids. Econ. Geol. 2005, 100, 863-886. [CrossRef]

63. Yu, G.; Chen, J.F.; Xue, C.J.; Chen, Y.C.; Chen, F.K.; Du, X.Y. Geochronological framework and Pb, Sr isotope geochemistry of the Qingchengzi Pb-Zn-Ag-Au orefield, Northeastern China. Ore Geol. Rev. 2009, 35, 367-382. [CrossRef]

64. Tuduri, J.; Chauvet, A.; Barbanson, L.; Labriki, M.; Dubois, M.; Trapy, P.-H.; Lahfid, A.; Poujol, M.; Melleton, J.; Badra, L.; et al. Structural control, magmatic-hydrothermal evolution and formation of hornfels-hosted, intrusion-related gold deposits: Insight from the Thaghassa deposit in Eastern Anti-Atlas, Morocco. Ore Geol. Rev. 2018, 97, 171-198. [CrossRef]

65. Tuduri, J.; Chauvet, A.; Barbanson, L.; Bourdier, J.-L.; Labriki, M.; Ennaciri, A.; Badra, L.; Dubois, M.; Ennaciri-Leloix, C.; Sizaret, S.; et al. The Jbel Saghro Au (-Ag, Cu) and Ag-Hg Metallogenetic Province: Product of a Long-Lived Ediacaran Tectono-Magmatic Evolution in the Moroccan Anti-Atlas. Minerals 2018, 8, 592. [CrossRef]

66. Li, J.F. Chengde Fengning Niujuan Silver Deposit Genesis Analysis. Master's Thesis, Shijiazhuang University of Economics, Shijiazhuang, China, 2013. (In Chinese).

67. Zeng, Q.D.; He, H.Y.; Zhu, R.X.; Zhang, S.; Wang, Y.B.; Su, F. Origin of ore-forming fluids of the Haigou gold deposit in the eastern Central Asian Orogenic belt, NE China: Constraints from H-O-He-Ar isotopes. J. Asian Earth Sci. 2017, 144, 384-397. [CrossRef]

68. Li, L.; Sun, J.G.; Men, L.J.; Chai, P. Origin and evolution of the ore-forming fluids of the Erdaogou and Xiaobeigou gold deposits, Jiapigou gold province, NE China. J. Asian Earth Sci. 2016, 129, 170-190. [CrossRef]

69. Yoo, B.C.; Lee, H.K.; White, N.C. Mineralogical, fluid inclusion, and stable isotope constraints on mechanisms of ore deposition at the Samgwang mine (Republic of Korea) - A mesothermal, vein-hosted gold-silver deposit. Miner. Depos. 2010, 45, 161-187. [CrossRef]

70. Wilde, S.A.; Zhou, J.B. The late Paleozoic to Mesozoic evolution of the eastern margin of the Central Asian Orogenic Belt in China. J. Asian Earth Sci. 2015, 113, 909-921. [CrossRef]

71. Wilkinson, J.J.; Simmons, S.F.; Stoffell, B. How metalliferous brines line Mexican epithermal veins with silver. Sci. Rep. 2013, 3, 2057. [CrossRef] [PubMed]

72. Peter, G.V. Silver mineralization in the Rochester District, Pershing County, Nevada. Econ. Geol. 1981, 76, 580-609.

73. Deng, J.; Yuan, W.M.; Carranza, E.J.M.; Yang, L.Q.; Wang, C.M.; Yang, L.Y.; Hao, N.N. Geochronology and thermochronometry of the Jiapigou gold belt, northeastern China: New evidence for multiple episodes of mineralization. J. Asian Earth Sci. 2014, 89, 10-27. [CrossRef]

74. Groves, D.I.; Santosh, M. Province-scale commonalities of some world-class gold deposits: Implications for mineral exploration. Geosci. Front. 2015, 6, 389-399. [CrossRef]

75. Li, Z.K.; Li, J.W.; Chen, L.; Zhang, S.X.; Zheng, S. Occurrence of silver in the Shagou Ag-Pb-Zn deposit, Luoning County, Henan Province: Implications for mechanism of silver enrichment. Earth Sci. J. China Univ. Geosci. 2010, 35, 621-636. (In Chinese)

76. Fontboté, L.; Kouzmanov, K.; Chiaradia, M.; Pokrovski, G.S. Sulfide minerals in hydrothermal deposits. Elements 2017, 13, 97-103. [CrossRef]

77. Seward, T.; Barnes, H. Metal transport by hydrothermal ore fluid. In Geochemistry of Hydrothermal Ore Deposit, 3rd ed.; Barnes, H.L., Ed.; Wiley: New York, NY, USA, 1997; pp. 435-486.

78. Zhong, J.; Chen, Y.J.; Qi, J.P.; Chen, J.; Dai, M.C.; Li, J. Geology, fluid inclusion and stable isotope study of the Yueyang Ag-Au-Cu deposit, Zijinshan Orefield, Fujian Province, China. Ore Geol. Rev. 2017, 86, 254-270. [CrossRef] 
79. Kouzmanov, K.; Pokrovski, G.S. Hydrothermal controls on metal distribution in porphyry Cu (-Mo-Au) systems. In Geology and Genesis of Major Copper Deposits and Districts of the World: A Tribute to Richard H. Sillitoe; Hedenquist, J.W., Harris, M., Camus, F., Eds.; Special Publications of the Society of Economic Geologists: Lancaster, PA, USA, 2012; pp. 573-618.

80. Chai, P.; Sun, J.G.; Xing, S.W.; Li, B.; Lu, C. Ore geology, fluid inclusion and ${ }^{40} \mathrm{Ar} /{ }^{39} \mathrm{Ar}$ geochronology constraints on the genesis of the Yingchengzi gold deposit, southern Heilongjiang Province, NE China. Ore Geol. Rev. 2016, 72, 1022-1036. [CrossRef]

81. Zhang, X.B.; Wang, K.Y.; Fu, L.J.; Zhang, M.; Konare, Y.; Peng, D.W.; Cai, W.Y. Fluid inclusions, C-H-O-S isotope and geochronology of the Bujinhei $\mathrm{Pb}-\mathrm{Zn}$ deposit in the southern Great Xing'an Range of Northeast China: Implication for ore genesis. Resour. Geol. 2016, 67, 207-227. [CrossRef]

(C) 2019 by the authors. Licensee MDPI, Basel, Switzerland. This article is an open access article distributed under the terms and conditions of the Creative Commons Attribution (CC BY) license (http://creativecommons.org/licenses/by/4.0/). 